\title{
EL ESCULTOR JUAN DE CASTRO, CONTEMPORÁNEO Y ÉMULO DE FRANCISCO DE MOURE EN LA ZONA SUROCCIDENTAL DE ASTURIAS DURANTE EL PRIMER TERCIO DEL SIGLO XVII
}

Pelayo Fernández Fernández

Universidad de Oviedo

Data recepción: 2017/01/14

Data aceptación: 2017/04/05

Contacto autor: pelayoarte@gmail.com

ORCID: https://orcid.org/0000-0002-4933-8876

\section{RESUMEN}

Se da noticia de la actividad del escultor gallego Juan de Castro (doc. en 1626-1633), oriundo de Mondoñedo, un escultor de la misma generación de Francisco Moure y acaso colaborador suyo que difundió sus modelos y estilo en la zona suroccidental de Asturias. Con el asentamiento de Castro en las villas de Grandas de Salime y Cecos se inició lo que el profesor Germán Ramallo llamó el "Primer Taller de Cangas del Narcea"; que se consolidó con la actividad de su alumno y yerno, Pedro Sánchez de Agrela que, tras establecerse en la villa de Cangas de Tineo (hoy, del Narcea) hacia 1643, centralizó en un único y cualificado taller toda la actividad retablística e imaginera de esa extensa comarca, convirtiéndose en uno de los escultores y retablistas más competente de Asturias a mediados del siglo XVII, junto con Luis Fernández de la Vega.

Palabras clave: Juan de Castro, Grandas de Salime, Mondoñedo, imaginería, barroco

\section{ABSTRACT}

This article looks at the work of the Galician sculptor Juan de Castro (documented in 1626-1633). Born in Mondoñedo, he formed part of the same generation as Francisco de Moure and is thought to have worked closely with him, helping to disseminate his models and style through southwestern Asturias. When Castro moved to the villages of Grandas de Salime and Cecos, it marked the advent of what Professor Germán Ramallo called "the first workshop of Cangas del Narcea", which established itself thanks to the work of Castro's pupil and son-in-law Pedro Sánchez de Agrela, who, after moving to the town of Cangas de Tineo (as Cangas del Narcea was once known) in around 1643, centralised all altarpiece and religious imagery work undertaken in this extensive region at a single, specialised workshop. In the process he became one of the most skilled sculptors and altarpiece artists in the Asturias of the mid-17th century, together with Luis Fernández de la Vega.

Keywords: Juan de Castro, Grandas de Salime, Mondoñedo, imagery, Baroque

El escultor y pintor mindoniense Juan de Castro fue, junto con Francisco de Moure (1575/15761636), uno de los principales representantes del protobarroco en las diócesis de Lugo y Mondo- ñedo y el fundador de lo que el profesor Germán Ramallo denominó en 1985 como "Primer Taller de Cangas del Narcea". Con este término definió la actividad escultórica radicada en Cangas de Ti- 
neo (hoy, del Narcea, Asturias), importante villa del suroccidente de Asturias, iniciada en torno a 1642, con la hechura del retablo mayor de la antigua colegiata (hoy, basílica) de Santa María Magdalena de dicha villa, fundada en 1639 por don Fernando de Valdés y Llano (Cangas de Tineo, 1575 - Madrid, 1639), arzobispo de Granada y Presidente del Consejo de Castilla, y cuya única cabeza visible, por entonces, era el escultor y arquitecto de retablos gallego Pedro Sánchez de Agrela' (San Pedro de Mor, Lugo, h. 1610 - Cudillero, Asturias, 1661), yerno y alumno de Juan de Castro.

Pero tras la realización de nuestra tesis doctoral sobre los talleres de escultura de la zona suroccidental asturiana (de Cangas y de Corias, principalmente) hemos demostrado que la actividad de aquel Taller se inició varios años antes, hacia 1626-1628, y que fue Juan de Castro, y no Sánchez de Agrela, quien en realidad impulsó la actividad escultórica en esta comarca asturiana, en los concejos limítrofes con la actual provincia de Lugo (Ibias, Pesoz y Grandas de Salime), implantando los modelos y el estilo de Francisco de Moure, acuñados en la sillería de coro de la catedral de Lugo en 1621 y, posteriormente, en el retablo mayor de la iglesia de La Antigua o de los Jesuitas en Monforte de Lemos, en 1625, fundación del cardenal don Rodrigo de Castro. Su estilo de madurez (prenaturalista) se caracteriza por una valoración más real y afectiva de los gestos y actitudes de las figuras, y por una mayor complejidad y claroscurismo en el tratamiento de las telas. Estos elementos ya se habían empezado a manifestar desde el último cuarto del siglo XVI en otros focos artísticos de la mitad norte peninsular: primero, en los trabajos del Taller de Toro (Juan y Sebastián Ducete y Esteban de Rueda), en las diócesis de Zamora y Oviedo, y luego y más conscientemente con Francisco del Rincón ( $h$. 1567-1608) y Gregorio Fernández (1576-1636), en la de Valladolid².

Esta implantación del arte de madurez de Francisco de Moure en la periferia suroccidental de Asturias se produjo con el asentamiento de Juan de Castro, primero en la villa de Grandas de Salime (1626/1628-1631) para trabajar el retablo mayor de la colegiata de San Salvador ${ }^{3}$ y, a renglón seguido entre 1631 y 1633, en la de
Cecos (en el concejo de Ibias), amparado por el linaje de los Ron, patronos del templo parroquial de Santa María. El traslado de Castro a la villa de Grandas estaría motivado porque tanto en Lugo como en Mondoñedo le sería muy complicado competir con Moure y su taller. En cambio, en la periferia de esas diócesis y en el extremo occidental de la de Oviedo, no existían imagineros ni retablistas cualificados y a Castro le sería por tanto, más fácil conseguir un mercado nuevo en un momento que coincidió con el despertar de la actividad imaginera y con la implantación del retablo escultórico en ambientes no urbanos ni monásticos. El momento, además, coincide con un periodo de bonanza económica en el que tuvo mucho qué ver la extensión de nuevos cultivos, como el maíz 4 .

De la temprana actividad de Juan de Castro en Galicia, solo tenemos documentada una obra: el retablo de la capilla de la Inmaculada Concepción de la catedral de Mondoñedo para el señor don Álvaro Pérez Osorio y su esposa doña María, marquesa de Miranda, un encargo de 1626 por el que solo percibió 375 reales 5 . Lo más probable es que esta marginalidad, unida a una muy escasa cartera de pedidos (ya por entonces monopolizada en lo sustancial y relevante por Francisco Moure), determinara a que Castro, cuando se pusieron en conocimiento los autos y proclamas para hacer el retablo mayor de la colegiata de Grandas de Salime en la ciudad de Mondoñedo en 1626, viese en este trabajo la oportunidad para dar un giro en su carrera profesional e instalarse lejos del radio de acción del taller de Moure y poder desarrollar una actividad independiente y mejor remunerada. De hecho, en 1630, una vez acabado el retablo de Grandas, Castro no regresó a Galicia, sino que se instaló en la villa de Cecos (Ibias, Asturias), donde le sorprendió la muerte en 1633.

En esta villa, Castro trabajó en el alhajamiento del templo parroquial de Santa María: hizo el retablo de Nuestra Señora del Rosario y tal vez inició el acondicionamiento y alhajamiento del presbiterio, con la hechura del primer retablo mayor y los sepulcros bajo arcosolios de la familia Ron que se culminaron años más tarde, en 1681, según relatan sendas inscripciones ${ }^{6}$. También a su taller debemos el retablo de la capilla de la Virgen 
de la Esperanza de Malneira (Grandas de Salime), una fiel reproducción en blanco del anterior.

Este taller formado por Castro tendrá su éxito y expansión diez años después con la actividad de su yerno y discípulo, Pedro Sánchez de Agrela, avecindado hacia 1642-1643 en la villa de Cangas de Tineo, que a partir de entonces se convertiría en la capital artística de toda la comarca suroccidental asturiana y cuyo radio de acción se expandió hacia otras zonas de las provincias de Asturias, El Bierzo, León, Lugo e incluso Valladolid a partir de la colaboración con Fernández de la Vega en los retablos colaterales de la iglesia del antiguo monasterio de la Purísima Concepción de agustinas recoletas (hoy, convento de padres carmelitas) de Medina del Campo (Valladolid) patrocinados por el obispo de Oviedo, don Bernardo Caballero de Paredes`, en 1650.

\section{El escultor Juan de Castro}

Las noticias sobre Juan de Castro son todavía muy escasas y limitadas, sobre todo en lo referente a una hipotética relación profesional con Francisco de Moure y a los oficiales que trabajaron a su servicio durante sus seis años de residencia en Asturias.

La primera referencia documental sobre Juan de Castro la aportó Pablo Pérez Costanti quien notició que en 1626, siendo vecino de Mondoñedo, recibió de don Álvaro Pérez Osorio el encargo de pintar el nuevo retablo que este tiene hecho en su capilla de la Concepción de la catedral de Mondoñedo y una imagen de Nuestra Señora de la Concepción, «nueva de su mano» y otra de San Pedro, «muy bien acabada», de tres palmos de alto con su peana, por 375 reales $^{\text {. }}$.

En 1985, Ramallo documentó por suyo el retablo mayor de la colegiata de San Salvador de la villa de Grandas de Salime y ya dejaba entrever que Juan de Castro pudo ser uno de los oficiales de Francisco de Moure en las obras del coro de la catedral de Lugo, iniciado en 1621. En la obra de Castro vislumbró Ramallo una doble influencia: la manierista palpable en la arquitectura de sus retablos y una protobarroca (o mejor, prenaturalista) en una captación más realista de los gestos y actitudes, y en la multiplicación y movimiento de los pliegues, en la línea de Moure ${ }^{10}$.
Recientemente, hemos estudiado la personalidad de Juan de Castro y profundizado en esa hipotética relación profesional con Moure y su taller, aportando documentación e identificando nuevos trabajos, lo que nos ha permitido elaborar un catálogo razonado de su producción en Asturias ${ }^{11}$.

\section{Reseña biográfica}

Ignoramos el año de su nacimiento, aunque seguramente se produjo a lo largo del último cuarto del siglo XVI y en la actual provincia de Lugo, acaso en la ciudad de Mondoñedo, pues en el testamento de su hija, Francisca de Castro, otorgado en la villa de Cangas de Tineo en 1654, se hace referencia a propiedades en esta ciudad.

Yten, digo que Pedro de Agrela, mi marido, la que la azienda que me perbiene en la ziudad de Mondonedo y que mientras Juan de Agrela, mi yjo, no fuere dioso para gozarla, la goze María de Agrela, la hermana de Pedro de Agrela'2.

Juan de Castro estuvo casado con Catalina Alonso, de la que tuvo, al menos, dos hijos: Francisca y Antonio. La primera contrajo matrimonio en 1637, en Cecos (Ibias, Asturias), con el ensamblador Pedro Sánchez de Agrela, debiendo solicitar los novios dispensa para poder casarse porque entre ellos había una «deuda de consanguinydad, tercio con quarto», lo que supone un grado de parentesco de primos en segundo grado $^{13}$. Francisca de Castro falleció en Cangas el 3 de marzo de 1686.

En tres de marzo de mill seiscientos y ochenta y seis años se murió Francisca de Castro, viuda de Pedro de Agrela; administráronle los Santos Sacramentos de la Yglesia y está enterrada en esta yglessia parrochial de la Magdalena de Cangas; hico memoria de testamento, y por verdad lo firmo ${ }^{14}$.

Por su parte, Antonio de Castro fue bautizado el 21 de mayo de 1631 en la colegiata de Grandas de Salime.

En veinte y uno de mayo de mil y seiscientos y treinta y uno, bapticé a Antonio, hijo de Juan de Castro, escultor, y de Catalina Alonso, su muger. Digo que le exorciçé y esgrimé, al qual hauía hechado agua de socorro y baptizado Domingo Fernández de Argul a quien esaminé en la forma del bautismo y la dixo 
bien. Tubieron el niño a los exorcismos y chatecymos el señor don Lope Núñez de Ron, mayorazgo de la casa de Ron, y Aldonça Rodríguez de Castrillón, muger de Marcos de Monteserín, vecino desta villa. Entre renglones, bautizado, Valga ${ }^{15}$.

Por ahora, no se ha podido comprobar si hubo un vínculo familiar entre Juan de Castro y el también escultor José de Castro (documentado en 1653), del que sabemos que en 1653 realizó el retablo mayor de la iglesia de San Pedro de Villayón (Asturias) ${ }^{16}$. Por el apellido y mismo oficio, acaso podría ser un pariente suyo, quizás hijo o si no, sobrino, que trabajó en el litoral costero occidental de Asturias durante el segundo tercio del siglo XVII. Si en realidad fuese hijo de Juan de Castro, esta circunstancia comportaría la existencia de un entramado familiar que abasteció de obra a todo el occidente asturiano: por una parte, el taller Pedro Sánchez de Agrela asentado en la villa de Cangas de Tineo, cuyo radio de acción se extendió por la zona suroccidental asturiana y las comarcas del norte de la actual provincia de León (Laciana y Babia), el Bierzo (León), Fonsagrada (Lugo) y Valladolid (Median del Campo); y el de José de Castro asentado en alguna localidad del occidente costero desde donde podría trabajar para toda la marina del extremo occidental de Asturias (concejos de Navia, Coaña, El Franco, Tapia de Casariego y Castropol).

Juan de Castro murió en Cecos (Ibias), el 26 de diciembre de 1633.

A veinte y seis de diciembre de 1633 muere Juan de Castro, escultor, administrado de los Santos Sacramentos y con el testamento a de hacerlo ${ }^{17}$.

Como decíamos, Juan de Castro fue el maestro y suegro de Pedro Sánchez de Agrela, ya que estaba casado con una hija suya, Francisca. Fruto de este matrimonio fueron Juan, Vicente y María Ana Sánchez de Agrela y Castro, nietos de Juan de Castro.

A Juan lo bautizaron en la colegiata de Cangas, el 19 de marzo de $1645^{18}$. Fue eclesiástico, con el título de licenciado, pero también se mantuvo ligado al mundo artístico. Principalmente, actuó como oficial de Pedro Sánchez de Agrela pero también se le documenta una obra como artista independiente: un Santo Cristo en 1666 para Juan Rodríguez de Tandés, apodado «Juanetón».
Fue policromado por el pintor Luis González Carballo (documentado en 1659-1666), vecino de la villa de Cangas de Tineo ${ }^{19}$. Juan Sánchez de Agrela falleció en la villa de Cangas, el 7 de enero de $1687^{20}$. También estuvo encargado, junto a su madre, de contratar a los maestros que terminaron las obras que quedaron inacabadas a la muerte de su padre.

De Vicente Sánchez de Agrela, bautizado en Cangas el 20 de abril de $1650^{21}$, nada sabemos ni si tuvo formación artística.

Finalmente, a María Ana la bautizaron en Cangas el 6 de junio de $1658^{22}$. El 16 de febrero de 1687 se casó con el ensamblador local Manuel de Ron y Llano (Peján, Cangas del Narcea, hacia 1645-Cangas del Narcea, 1732)23, que continuó con la actividad del taller heredado de Pedro Sánchez de Agrela, hasta finales del primer tercio del siglo XVIII. Manuel de Ron fue, junto al ensamblador Antonio López de la Moneda Díaz (O Cebreiro, Lugo, 1654-Corias, Cangas del Narcea, 1724) ${ }^{24}$, quien difundió por toda la comarca suroccidental asturiana el estilo barroco decorativo y el retablo de orden salomónico derivado del retablo mayor del monasterio benedictino de San Juan Bautista de Corias, contratado en 1677 por el arquitecto Francisco González y el escultor Pedro del Valle, vecinos de Villafranca del Bierzo ${ }^{25}$. María Ana falleció en Cangas, el 24 de octubre de $1699^{26}$.

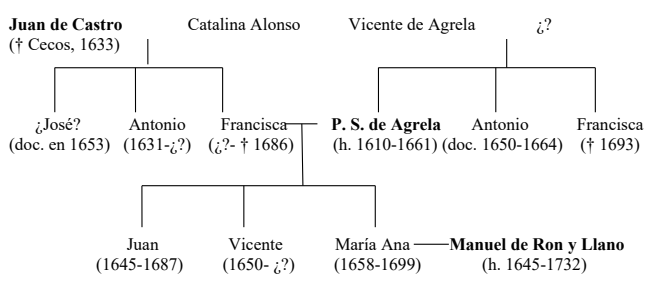

Sucesión generacional del taller fundado por Juan de Castro.

Juan de Castro y Francisco de Moure: evidencias

formales de una probable relación profesional

Desconocemos en qué obrador y con qué maestro se formó Juan de Castro. Ramallo ya apuntó una posible relación profesional con el escultor Francisco de Moure (1575/1576-1636) que, aunque no documentada, le parecía lógica y evidente, y no sería descabellado pensar en que Juan de Castro hubiese sido oficial de Moure en la sillería de coro de la catedral de Lugo, iniciada 


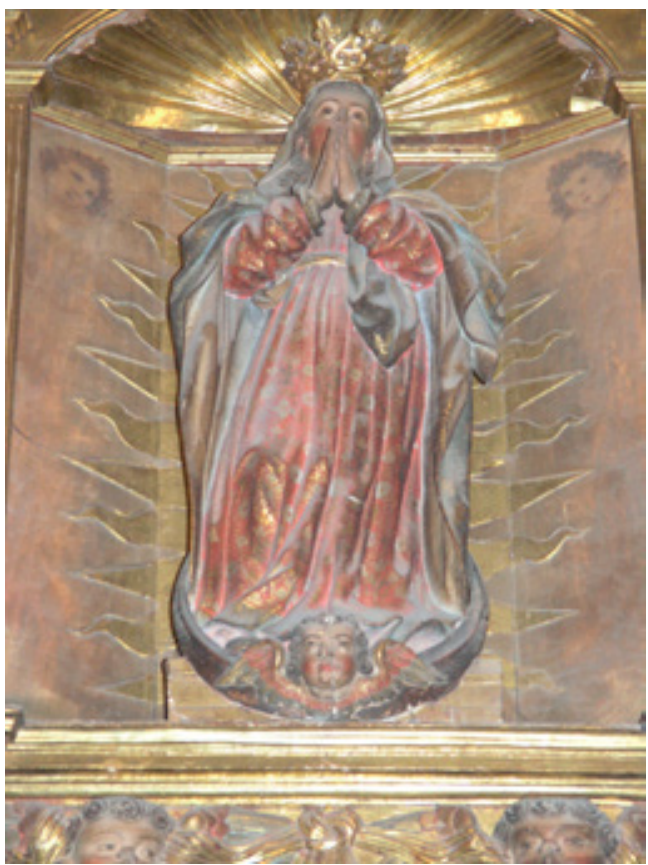

Fig. 1. Juan de Castro, Inmaculada Concepción, 1626, capilla de la Concepción, catedral de Mondoñedo

en 1621, y el retablo mayor del colegio de la Compañía en Monforte de Lemos, en 162527.

Francisco de Moure, contemporáneo estricto de Gregorio Fernández (1576-1636), era natural de Santiago de Compostela, donde nació a finales de 1575 o principios de 1576. En 1594 entró en el obrador del escultor Alonso Martínez, figurando ya como maestro independiente en 1598. En torno a 1615, se trasladó al monasterio benedictino de San Salvador de Samos (Lugo), donde hizo cinco retablos, y posteriormente en 1621, a Lugo, para trabajar en la sillería de coro de la catedral. Tras ello, se asentó en Monforte de Lemos (Lugo), firmando el 16 de noviembre de 1625 la escritura por la que se comprometía a realizar el retablo mayor de la iglesia de Nuestra Señora de la Antigua, del colegio de los jesuitas fundado por el cardenal don Rodrigo de Castro. Falleció en $1636^{28}$. Su primer estilo, influido por el manierismo, evolucionó hacia un prenaturalismo a partir de la segunda década del siglo XVII, palpable en la captación de gestos y actitudes realistas, y un claroscurismo en el tratamiento de las telas. Precisamente, este naturalismo formal fue lo que Castro incorporó a su obra a partir de

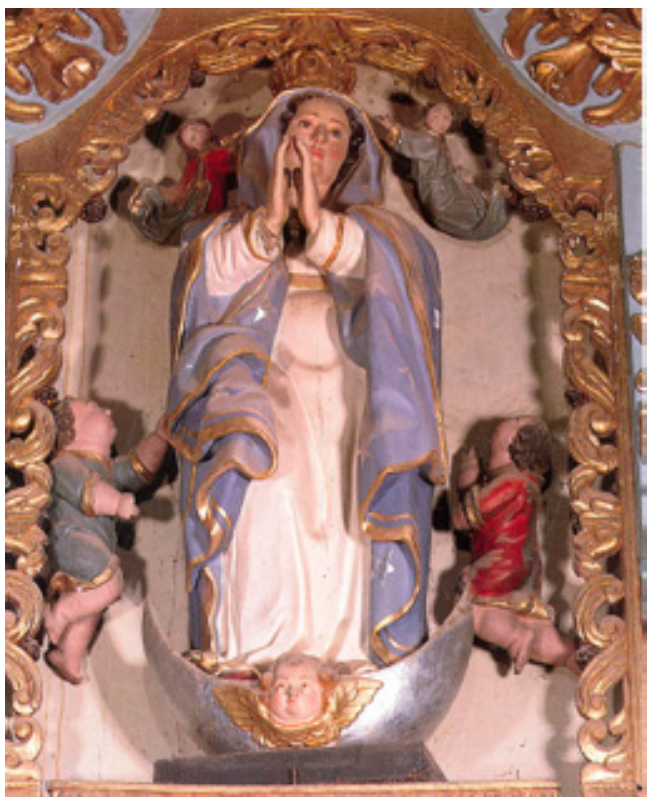

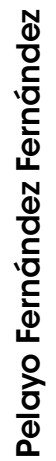

Fig. 2. Francisco de Moure, Inmaculada Concepción, h. 1604 retablo de Santa María de Arnuide (Orense). Fotografía de M. D. VILA JATO, Francisco de Moure, Santiago, Xunta de Galicia, 1991, p. 49

1626, aunque de manera menos fina y consciente que Moure.

En cambio, a la luz de lo que hoy sabemos, no creemos que el aprendizaje de Castro fuese como sospechaba Ramallo, en el obrador de Francisco de Moure, sino que de este tan solo asimiló los modelos iconográficos y ese estilo protobarroco arriba descrito, como se ve en las imágenes del retablo mayor de la colegiata de San Salvador de Grandas de Salime. En primer lugar, el asentamiento de Moure en Lugo data de 1621, fecha tardía para situar a partir de entonces el aprendizaje de Castro ya que, poco después, en 1626 estaba trabajando por cuenta propia un retablo para una capilla particular en la catedral de Mondoñedo, siendo, por tanto, un oficial formado, un sujeto maduro y de cierto prestigio. El aprendizaje de Castro, por tanto, hubo de producirse previamente a 1621 y en el taller de algún pintorescultor activo a finales del siglo XVI o principios del XVII. Que este pudiera haber sido Moure no lo descartamos, pero bien entendido que tuvo que ser antes de 1621, pues su nombre no figura en la nómina conocida de oficiales que asistieron a Moure en Lugo. 


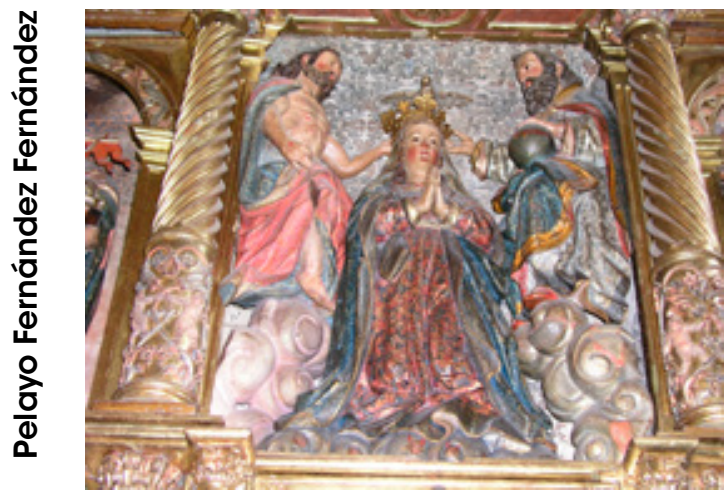

Fig. 3. Juan de Castro, Coronación de la Virgen, h. 1628-1630, retablo mayor de la colegiata de San Salvador, Grandas de Salime

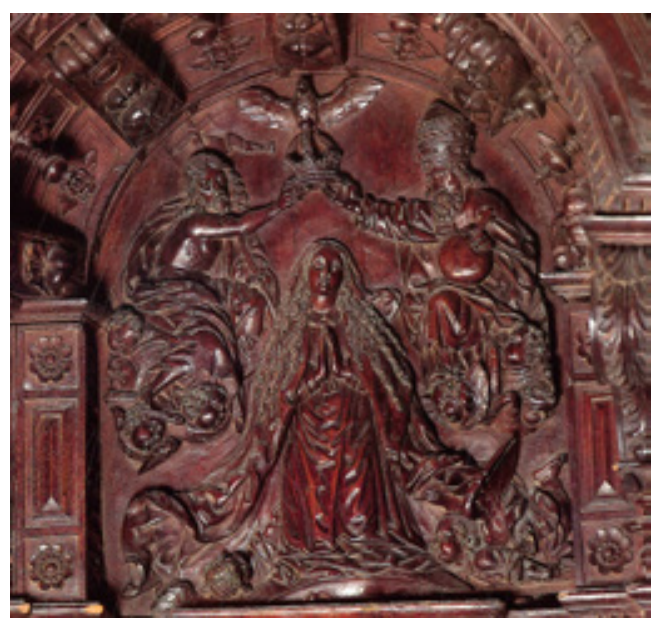

Fig. 4. Francisco de Moure, Coronación de la Virgen, h. 1621, sillería de coro, catedral de Lugo. Fotografía de M. D. VILA JATO, Francisco de Moure, Santiago, Xunta de Galicia, 1991, p. 121

Pero lo que resulta indudable es que Castro conoció la producción del Moure maduro y con personalidad ya asentada y diferenciada. Pero solo una vez instalado Francisco de Moure en Lugo es cuando Castro entraría en contacto con su estilo y modelos, de cierta estirpe naturalista, como demuestra la imagen de la Inmaculada Concepción de la catedral de Mondoñedo y la imaginería del retablo mayor de la colegiata de Grandas de Salime.

La primera (fig. 1) sigue el modelo de la Inmaculada de la iglesia de Santa María de Arnuide (Orense) contratada por Moure el 23 de enero de 1604 (fig. 2), aún muy influida por el estilo

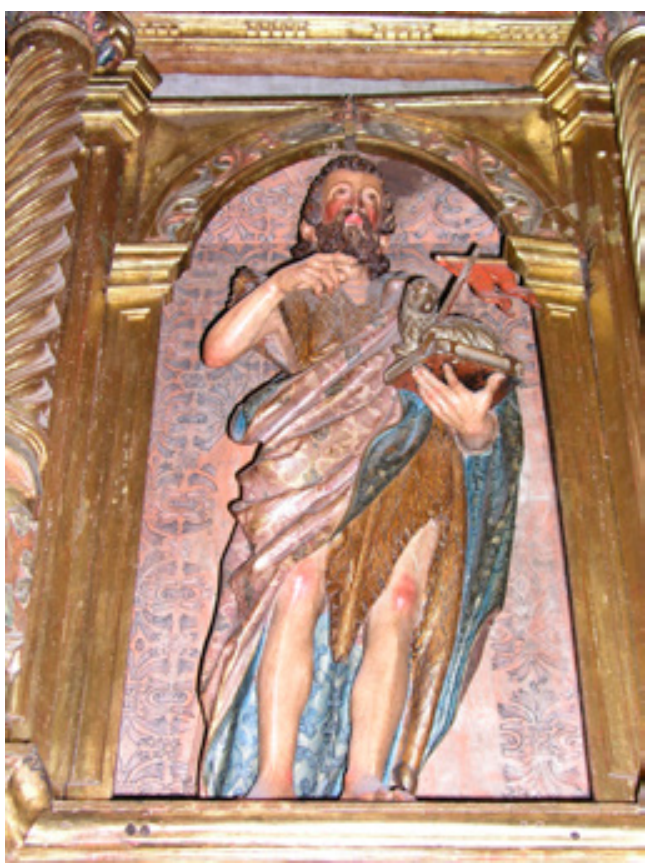

Fig. 5. Juan de Castro, San Juan Bautista, h. 1628-1630, retablo mayor, colegiata de Salvador, Grandas de Salime

manierista aprendido en su formación. A juicio de Vila Jato, deriva de la que Juan de Angés el Mozo había hecho para el retablo de Xunqueira de Espadañedo29. En este caso, Castro, al igual que Moure, parte del modelo quinientista y aunque el Ángel de Castro está tomado de la obra de Moure; a diferencia de esta se ve una cierta evolución hacia el naturalismo vallisoletano, palpable en el tratamiento de las telas con un plegado más duro y monumental.

En el grupo de la Coronación de la Virgen del retablo de Grandas (fig. 3), Castro se inspiró en el relieve de la sillería coral de la catedral de Lugo (fig. 4). En él, y a diferencia de la Inmaculada de Arnuide, Moure ya sigue el modelo impuesto en la zona norte de España por Gregorio Fernández, caracterizado por la simetría y frontalidad en el tratamiento y distribución de la figura: el manto que cae simétrico a ambos lados del cuerpo; el cabello dividido en dos crenchas sobre los hombros y las manos juntas y rectas sobre el pecho ${ }^{30}$.

De Moure también asimiló Castro el modelo de san Juan Bautista. La imagen del Precursor del retablo de Grandas (fig. 5), con toda la rudeza de su 


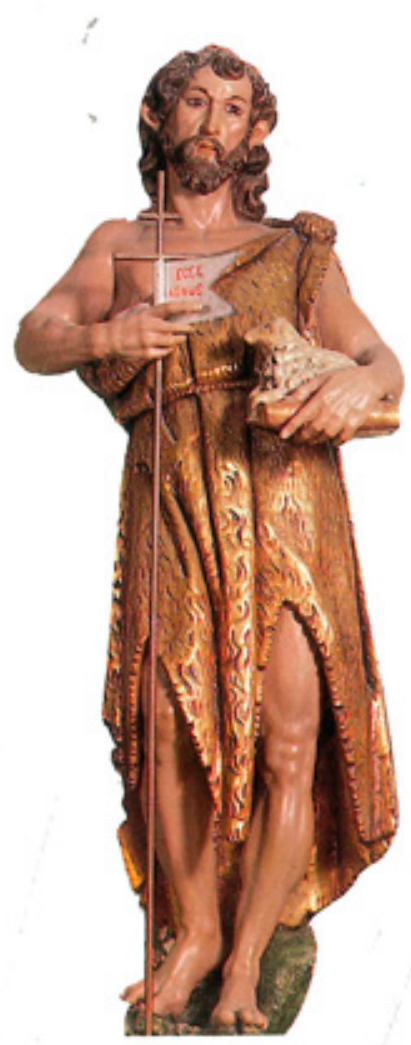

Fig. 6. Francisco de Moure, San Juan Bautista, h. 1615, retablo de Rairiz de Veiga (Orense). Fotografía de M. D. VILA Jato, Francisco de Moure, Santiago, Xunta de Galicia, 1991, p.73

estilo, quiere imitar el del retablo de Rairiz de Veiga (Orense), realizado por Moure hacia 1615 (fig. 6). Según Vila Jato, este San Juan representa un punto intermedio entre el de la iglesia de Arnuid y su modelo más famoso y señero, el del monasterio benedictino de Samos (Lugo) ${ }^{31}$. Modelo que posteriormente será utilizado por alguno de los seguidores de Castro en el retablo de la capilla ViIlamil-Illano de la iglesia parroquial de Santiago de Pesoz (Asturias), hecho en 1638, acaso por Pedro Sánchez de Agrela, como se verá a continuación.

Para representar a Santiago el Mayor (fig. 7) parece que Castro se inspiró en el tipo de Moure, como revela la confrontación con el existente en la capilla de San Juan de la catedral de Orense (fig. 8). Aunque, como en el caso de la Inmaculada Concepción de la catedral de Mondoñedo, se distancia de More en el tratamiento de las telas.

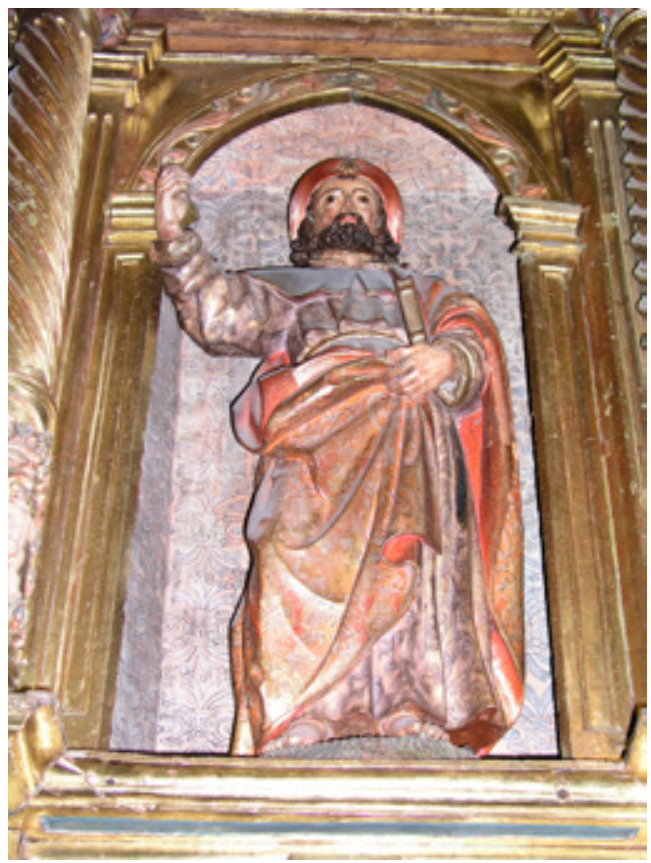

Fig. 7. Juan de Castro, Santiago, h. 1628-1630, retablo mayor, colegiata de San Salvador, Grandas de Salime

En cambio, en otras imágenes, Castro se aleja de la obra de Francisco de Moure. Es el caso de la imagen de San Pablo de Grandas (fig. 9) que aunque parece inspirarse en la del retablo de Rairiz de Veiga (fig. 10), con el libro en la mano izquierda y con la diestra empuña la espada, el estilo es bastante diferente ya que el de More es juniano aún y el de Castro, tira más al naturalismo vallisoletano por la influencia de la obra de Gregorio Fernández como se percibe en la frontalidad y tratamiento más rígido y duro de los pliegues.

Finalmente, a Santa María Magdalena del retablo de Grandas de Salime la representó como una mujer joven, una cortesana arrepentida, aún con su lujosa indumentaria y con el tarro de afeites en la mano, en la tradición del modelo medieval, que pervive aún manierista, y modelo que repetirá Sánchez de Agrela en el retablo de la colegiata de Cangas del Narcea en fecha tan tardía como 1643-1645.

Por tanto, el estilo maduro de Moure, concretado tras su asentamiento en Lugo, ejerció una visible influencia en la obra de Castro y ulteriormente en la de su discípulo Pedro Sánchez de 


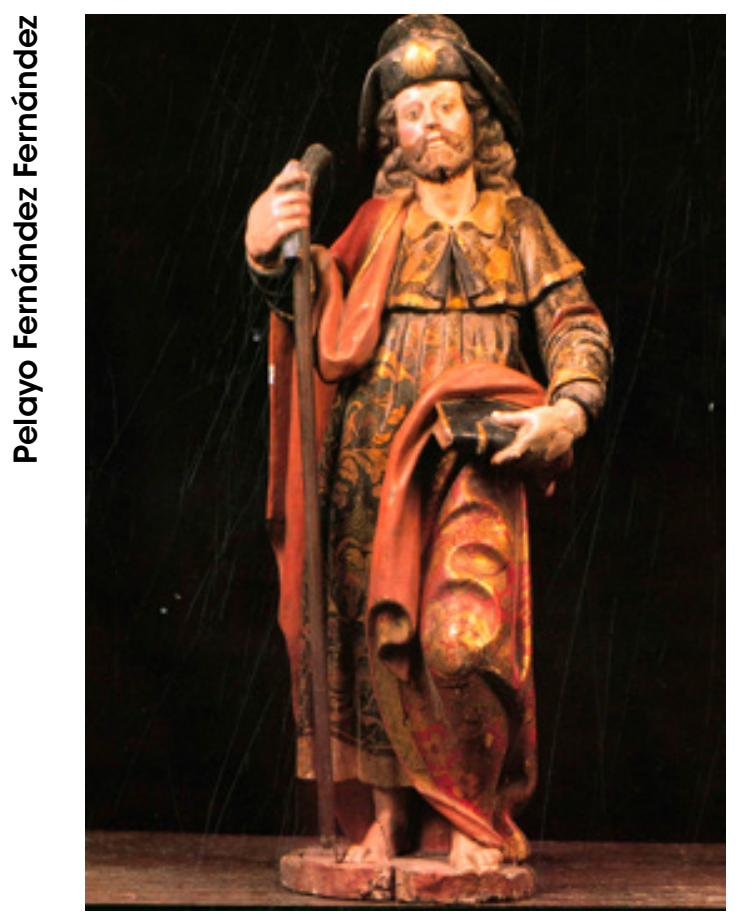

Fig. 8. Francisco de Moure, Santiago, h. 1615, catedral de Orense. Fotografía de M. D. VILA JATO, Francisco de Moure, Santiago, Xunta de Galicia, 1991, p. 34

Agrela, como luego veremos. No obstante, en la obra de Castro y, como no, en la de Sánchez de Agrela se constata una clara evolución hacia el naturalismo vallisoletano palpable en la frontalidad y simetría de las figuras, y en el tratamiento monumental y más duro de los pliegues. Esta dualidad de la que estamos hablando se percibe claramente en las imágenes del retablo mayor de Grandas de Salime.

\section{Taller y estilo de Juan de Castro}

Juan de Castro vino a Asturias con su familia (esposa e hija) y además se trajo a sus propios oficiales pero solo conocemos el nombre de dos: Pedro Sánchez de Agrela y Rodrigo Álvarez.

El primero, su futuro yerno y acaso pariente, si no suyo, de su esposa, porque cuando Agrela desposó a la hija de Castro tuvo que pedir dispensa por «deuda de consanguinydad, tercio con quarto». Sabemos que Sánchez de Agrela serró y preparó las maderas para el retablo de Grandas, teniendo constancia suya como maestro inde-

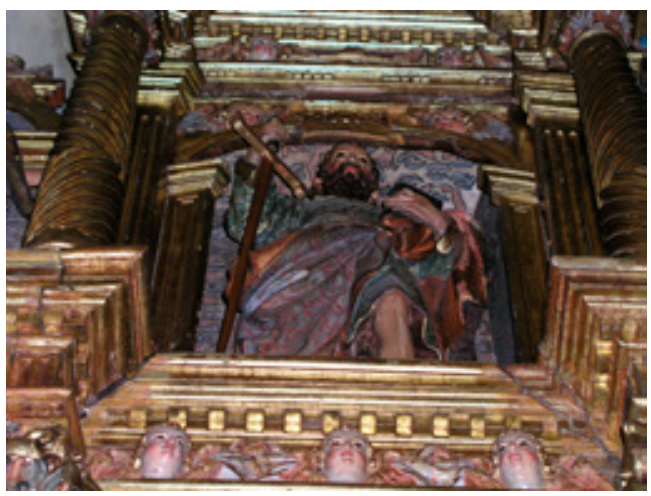

Fig. 9. Juan de Castro, San Pablo, h. 1628-1630. Retablo mayor, colegiata de San Salvador, Grandas de Salime

pendiente en 1634, casi un año después de la muerte de Castro, momento en que ajustó en la villa de Cecos (Ibias), el retablo mayor de la iglesia parroquial de Santa María, en Suárbol (Ancares, León) ${ }^{32}$. Del segundo, Rodrigo Álvarez, solo consta que era cuñado de Juan de Castro, ignorando su actividad profesional tanto en Asturias como fuera de ella.

Estilísticamente, Juan de Castro fue un maestro a caballo entre el manierismo tardío de filiación postjuniana y el naturalismo barroco. Como ensamblador, se mantuvo fiel a los modelos del último cuarto del siglo XVI. En sus retablos, hay columnas de fustes torsos, con el tercio inferior labrado con cartelas y angelitos desnudos, o simplemente torsos; cabezas de querubines recorriendo los frisos, y el busto Dios Padre, en el tímpano. En cambio, en cuanto escultor-imaginero, al menos en su fase documentada, que corresponde a los últimos ocho años de su vida (1626-1633), anuncia el tránsito hacia el naturalismo barroco, con una buena disposición para la captación realista de las expresiones y gestos, y una multiplicación y movimiento de los pliegues, por influencia que en él tuvo la obra de madurez de Francisco de Moure. Es de reseñar la calidad de los peinados y barbas, con efectos de claroscuro. Por lo general, los rostros femeninos están enmarcados por largos y lisos cabellos, mientras que los masculinos peinan en cortas melenas de mechones ondulados. 


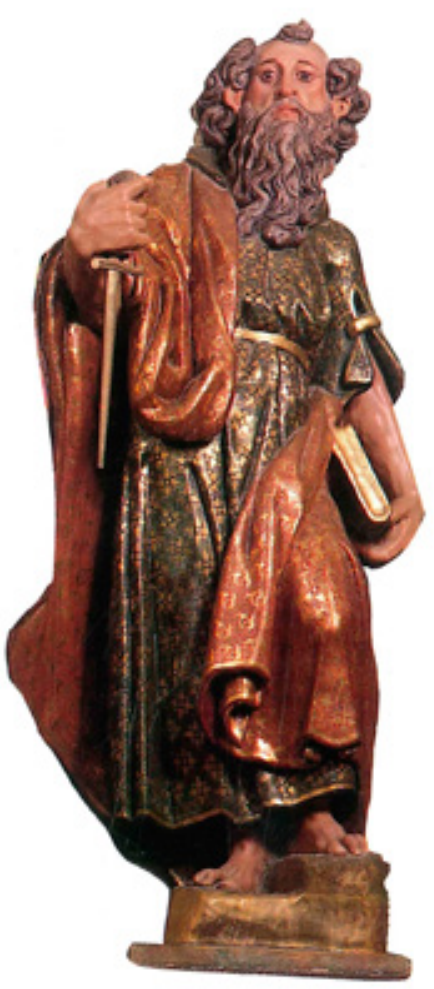

Fig. 10. Francisco de Moure, San Pablo, 1615, retablo de la iglesia de Rairiz de Veiga (Orense). Fotografía de M. D. VILA Jato, Francisco de Moure, Santiago, Xunta de Galicia, 1991, p. 73

\section{La obra de Juan de Castro}

La producción de Juan de Castro documentada o atribuida no es muy abundante. A continuación presentamos en esbozo un catálogo razonado de ella.

\section{1.- Imágenes de la Inmaculada Concepción y San Pedro, catedral de Mondoñedo}

Como ya quedó dicho, la trayectoria documental de Juan de Castro se inició en 1626, con su intervención en la capilla de la Concepción en la nave del trasaltar de la catedral de Mondoñedo, un recinto fundado en 1615 por don Álvaro Pérez Osorio y su esposa doña María, marquesa de Miranda ${ }^{33}$.

En 1626, Pérez Osorio encargó a Castro policromar el nuevo retablo que tenía hecho en su capilla (fig. 11); una imagen de la Inmaculada

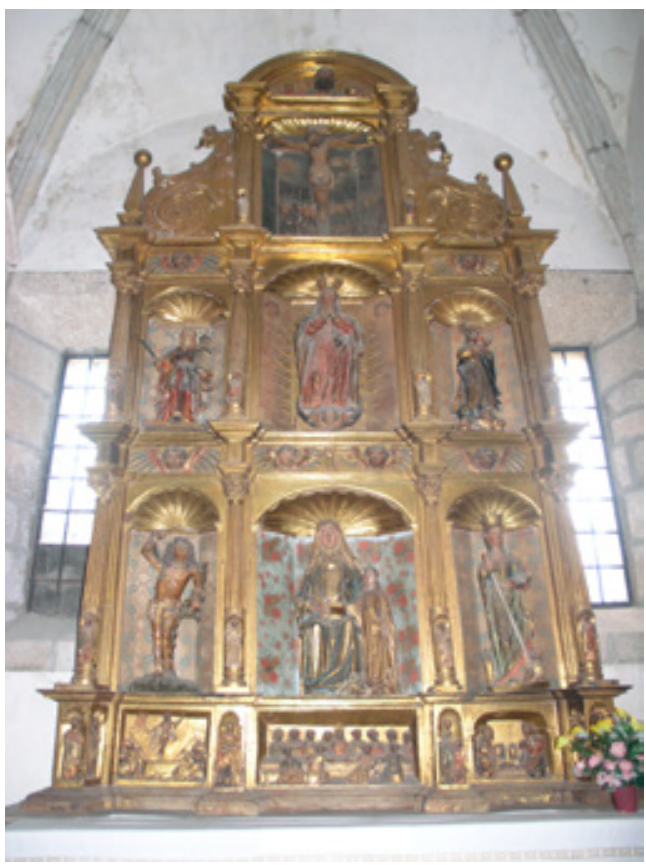

Fig. 11. Retablo de la Inmaculada Concepción, 1626, capilla de la Concepción, catedral de Mondoñedo. En la hornacina central, imagen de la titular (Juan de Castro)

Concepción, «nueva de su mano», y otra de San Pedro, "muy bien acabada», de tres palmos de alto (70 cm, aprox.) y la peana, por importe de 375 reales. Castro hizo las imágenes pero aunque también profesaba la pintura, no las doró, ni tampoco policromó el retablo, labor que se hizo más tarde, hacia 1639, como así se dice en el testamento de la marquesa de Miranda, otorgado en ese año:

[...] que quando se pintare mi capilla se pinte en el ueco del medio que alli hice para mi entierro una imagen de Nuestra Señora de la Concepción, y los retablos del dicho mi marido y mío a los lados [...] $]^{34}$.

Las imágenes fueron policromadas por los maestros compostelanos Francisco Velázquez y José Rodríguez, según lo dispusieron los albaceas de la señora marquesa ${ }^{35}$. La razón principal de que Juan de Castro no concluyese la obra pudo ser su traslado a Grandas de Salime para trabajar el retablo mayor de la colegiata, cuya construcción se ordenó en 1626.

De las dos imágenes realizadas por Castro solo la de la Inmaculada ha llegado a nuestros días ya 


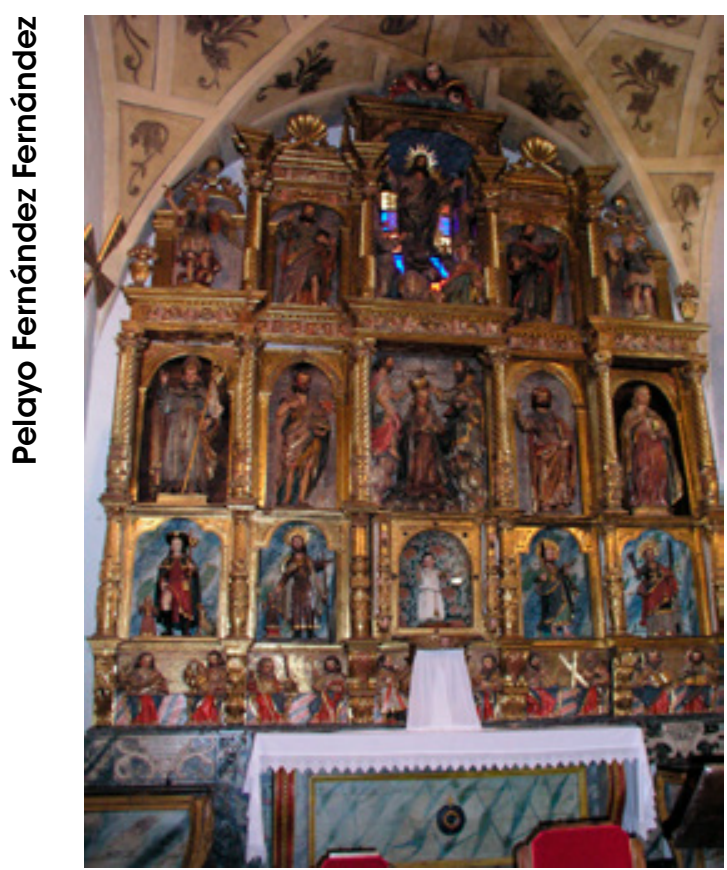

Fig. 12. Juan de Castro, retablo mayor, 1626-1630, colegiata de Sal Salvador, Grandas de Salime

que la de San Pedro fue robada. Se venera en la hornacina central de un retablo manierista, al parecer ajeno a su producción ya que el estilo de los relieves del banco (Nacimiento, Última Cena y Resurrección) y el Calvario del ático descubren otra mano, muy otra y diferente de la de Castro y de menor calidad ${ }^{36}$. Para representar el misterio de la Inmaculada, Castro empleó el mismo modelo que Francisco de Moure en el de la iglesia de Santa María de Arnuide (Orense) en 1604 (vid. fig. 2). Estilísticamente, la imagen de Castro anticipa un estilo más evolucionado, visible en la multiplicación de los pliegues, como ya quedó dicho.

En 1635, dos años después de la muerte de Castro, se hizo en la capilla, por orden de los albaceas de doña María un arcosolio con los escudos de los fundadores. Lo diseñó Diego lbáñez Pacheco, maestro mayor de la catedral de Mondoñedo ${ }^{37}$. En el medio del arcosolio hay una pintura de la Inmaculada y a sus lados, las figuras orantes de los fundadores de la capilla. Y en el basamento, esta inscripción:

ÁLVARO PÉREZ OSORIO Y DOÑA MARIA, MARQUESA DE MIRANDA, $Y$ SUS HEREDEROS SON PATRONOS DE ESTA CAPILLA POR HABER

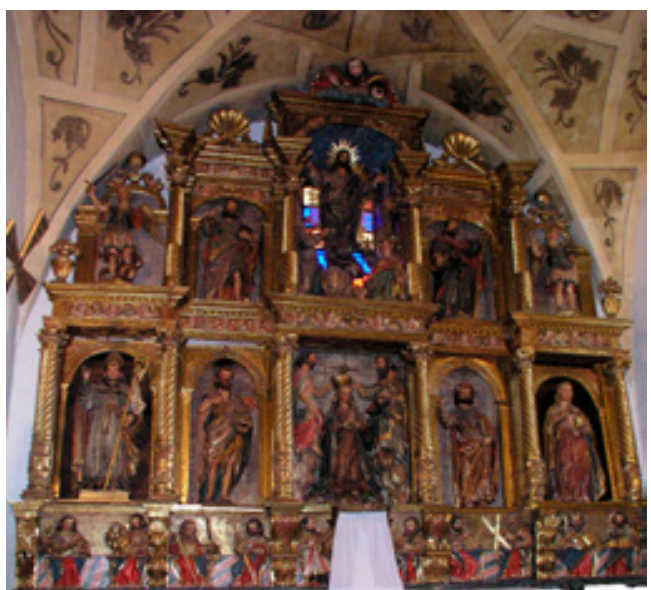

Fig. 13. Juan de Castro, reconstrucción del retablo mayor de la colegiata de Sal Salvador, Grandas de Salime, sin los añadidos del siglo xvIII

\section{SATISFECHO A LA FÁBRICA. DOTARON EN ELLA UNA MISA CADA DIA Y EN EL DE NUESTRA SEÑORA DE LA CONCEPCIÓN UNA CANTADA Y BISPERAS Y EL DIA DE SAN ANTONIO OTRA CON VIGILIA EN EL ALTAR MAYOR Y LAS HAN DE DECIR LOS SEÑORES DEL CABILDO Y DEJARON RENTA PARA QUE EN TODO EL OCTAVARIO DEL CORPUS HAYA CERA BLANCA Y PARA DOS ACÓLICOS QUE SIRVAN EL CORO Y CAPILLA. ADORNÁRONLA PARA SU ENTIERRO Y DE SUS HEREDEROS LIBRE DE TODA OTRA OBLIGACIÓN A LA FÁBRICA. MURIÓ ÁLBARO PÉREZ EN EL AÑO DE $1631^{38}$ \\ 2.- Retablo mayor de la colegiata de San Salvador en Grandas de Salime}

El retablo mayor de la antigua colegiata de San Salvador de Grandas de Salime (4,69 metros aproximadamente de anchura) es, hoy por hoy, la obra más importante y monumental de Juan de Castro.

Hito importante en la primitiva ruta jacobea, la fundación de la colegiata se remonta a los siglos XII-XIII, siendo ampliada a mediados del siglo XVI (tramo occidental de la nave y arranque de la torre) y totalmente renovada en el último tercio del XVIII, destacando la reforma del presbiterio que obligó a una modificación del retablo para adaptarse a su nueva altura (1771-1773). De la parte medieval tan solo se conserva la que fue portada principal y dos arcosolios góticos en el muro meridional de la nave ${ }^{39}$. 


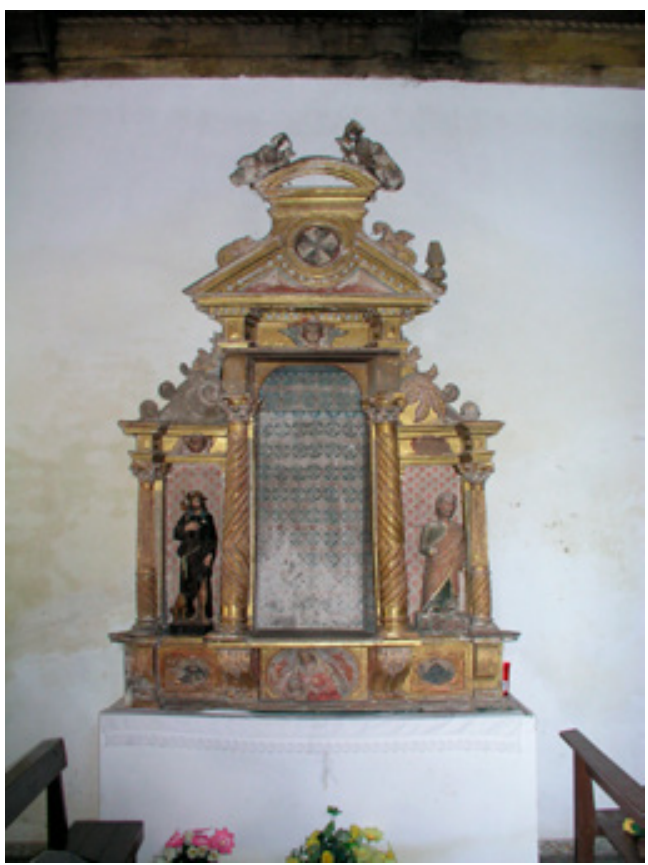

Fig. 14. Juan de Castro (atribución), retablo de Nuestra Señora del Rosario, h. 1630, iglesia parroquial de Santa María de Cecos (Ibias)

Según Madoz «el retablo mayor es antiquísimo, dorado y lleno de raros adornos que recuerdan la época del mal gusto» ${ }^{40}$.

Fue Ramallo quien lo documentó por obra de Juan de Castro en 1626, comenzándose poco después los pagos, y aclara que las hornacinas del primer piso y la parte inferior de los paneles del banco (parte inferior de Apostolado) se añadieron a mediados del siglo XVIIII1. Dichos añadidos fueron documentados por Javier González Santos como obra del escultor José Fagín Becerra (documentado en Asturias en 1761-1780), natural de La Coruña ${ }^{42}$, que trabajó en ellos entre 17711773, siendo abad de la colegiata don Matías Ignacio Menéndez, para adaptar el retablo a las dimensiones del nuevo presbiterio, como va di$\mathrm{cho}^{43}$.

El retablo (fig. 12) se inició entre 1626-1628, en tiempos del curato de Juan Rodríguez de Ron y de la mayordomía de Andrés López de la Braña. En la Visita apostólica del 22 de abril de 1626, don Jerónimo Bermúdez, visitador del partido de Grandas, mandó que se haga un «retablo con su custodia en la manera que al cura le pareciese»,

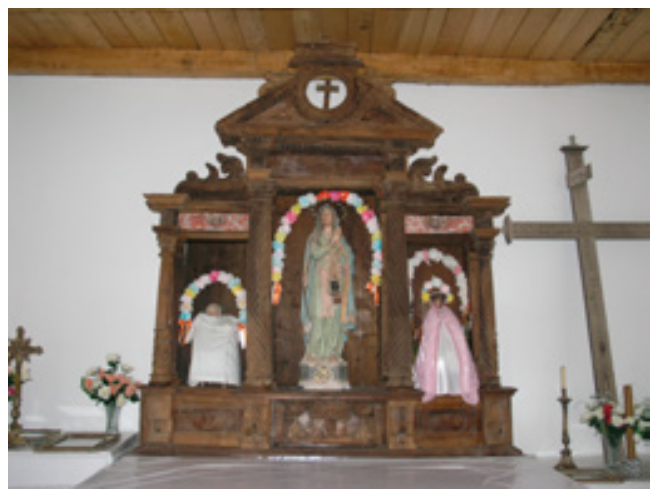

Fig. 15. Juan de Castro (taller de), retablo mayor, h. 1631 1633, capilla de la Virgen de la Esperanza, Malneira (Grandas de Salime)

dorado y estofado, y en un plazo desde el día de la visita hasta el de san Miguel (29 de setiembre) de 1626. Asimismo, ordenó que la obra se adjudicase por baja, poniendo autos y proclamas en las ciudades de Oviedo y Mondoñedo y en la villa de Ribadeo:

En la yglesia de San Salvador de Grandas, a veinte y dos días del mes de abril de seiscientos y veinte y seis años, su merced del señor licenciado don Jerónimo Vermúdez, visitador general de este obispado por su señoría, haviendo uisitado la dicha iglesia parroquial y en ella Santísimo Sacramento, Sanctos Óleos, pila bautismal y lo más que visitar se debía [...]. Otrosí, mandó su merced se aga un retablo y custodia en la manera que al cura le pareciese y si en dicho día que ay se siruiere, se dore y estofe por dentro y fuera, de forma que esté más deçente, y se cunpla ansí y se aga el concierto y se comienze a hacer desde aquí al día de San Miguel de septiembre que primero viene deste año, y se aga por bajas, poniendo el auto en Oviedo, Riuadeo y Mondoñedo, y lo cumpla el mayordomo y cura, pena de dos mil reales a cada uno si se dilatare por descuido y negligencia suya $[\ldots]^{44}$.

La obra la tomó a su cargo Juan de Castro, vecino de Mondoñedo, donde estaba trabajando en «los acomodos» de la capilla de la Asunción de la catedral. Desconocemos cuándo se iniciaron los trabajos del retablo de Grandas, aunque el 17 de setiembre de 1628 se registran los primeros 220 reales librados por la fábrica ${ }^{45}$ que prosiguieron hasta setiembre de $1629^{46}$. En la Visita de 1629 , se dice que el escultor tiene recibido 


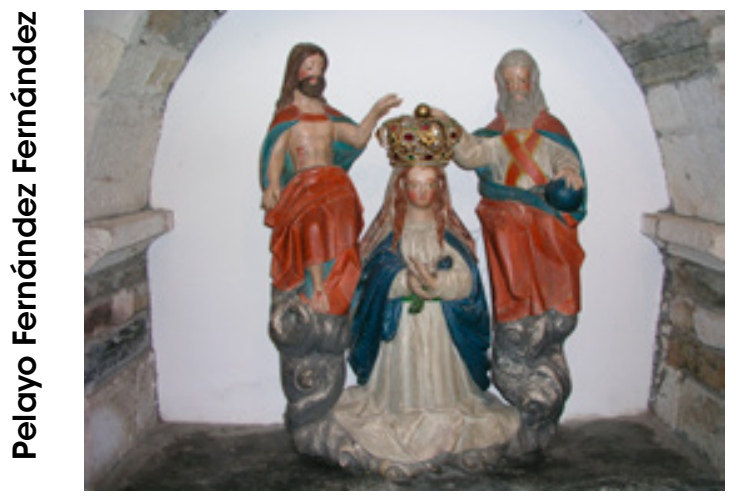

Fig. 16. Pedro Sánchez de Agrela (atribución), grupo de la Coronación de la Virgen, 1638, iglesia parroquial de Santiago, Pesoz

mucho dinero para esta obra, ordenándose que no se le dé «más blanca» hasta que no prosiga los trabajos:

Parece que el escultor que ace el rretablo desta yglesia tiene rescibido mucho para en quenta dél, y echo poca obra; mandó su merced que el cura y mayordomo no le den blanca asta que baya aciendo más obra, con apercibimiento que si yciere alguna falta en el dicho retablo corerá por su quenta [...].47

En 1630, las imágenes estaban por labrar, según se desprende del pago de 2 reales por el vino que se dio a un hombre por serrar un nogal para realizarlas, y 4 reales a Pedro Sánchez (de Agrela) por la madera que serró para el retablo ${ }^{48}$. Tras la muerte de Castro, los pagos se fueron sucediendo durante cinco años (1631), cuando Catalina Alonso, su viuda, se dio por satisfecha con las cantidades recibidas ${ }^{49}$.

En su hechura se utilizó madera de nogal. Exceptuando los añadidos del siglo XVIII, el retablo de Grandas se estructura en banco, frontispicio de cinco calles y ático también de cinco hornacinas. Destaca el retranqueo alternativo de las calles, originando un sencillo movimiento de planos y un entablamento quebrado, mantenidos en la ampliación de José Fagín. Todas las columnas del retablo original son de orden corintio: las del primer piso, con fustes torsos y el tercio inferior entallado con ignudi, tarjas y máscaras manieristas, cartuchos y borlas con motivos vegetales; y las del ático, también terciadas, pero con estriado torso alternante y enfrentado. El retablo remata en bolas y pirámides asimismo con estriado torso.

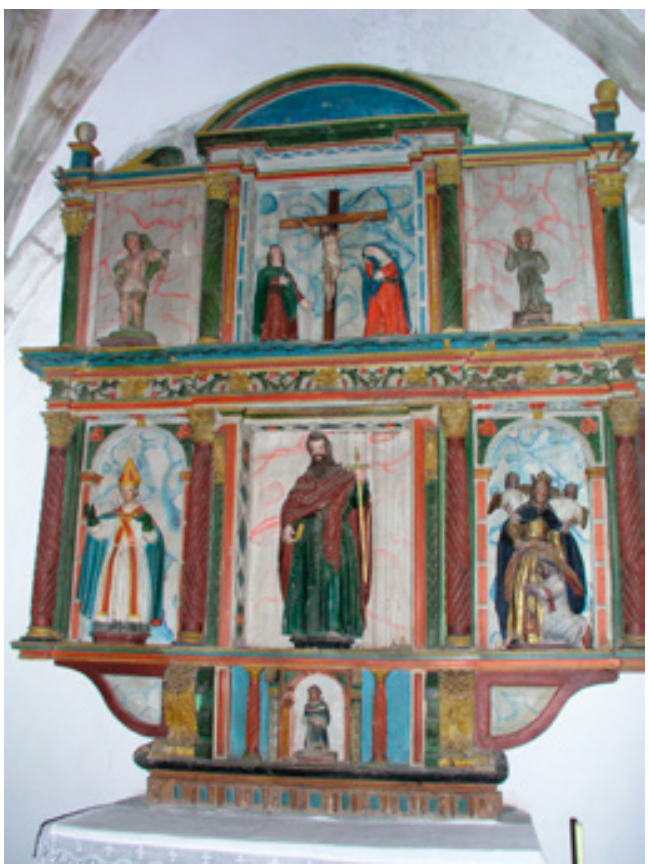

Fig. 17. Taller de Pedro Sánchez de Agrela (atribución), retablo de la capilla Villamil Illano, iglesia parroquial de Santiago, Pesoz, 1638

Desde el punto de vista ornamental, destacan las cabezas de querubines distribuidas por los frisos y en las enjutas de las hornacinas del ático; la pareja de jarrones, en los extremos del primer friso, y los motivos entallados en el tercio inferior de las columnas, como va dicho. Las hornacinas laterales del ático están rematadas por un frontón triangular y una vistosa y ostensible venera, motivo que se repite en los mensulones centrales de las calles laterales. Es este un motivo simbólico de gran expresividad y significado, dada la localización de Grandas y de su colegiata en el Camino de Santiago, siendo esta uno de los hitos fundamentales en la ruta jacobea primitiva.

La imaginería original debida a Castro es la siguiente. Relieves del banco: seis Apóstoles y los cuatro Evangelistas, de medio talle (la parte inferior es obra de Fagín), sedentes, agrupados en parejas, con sus atributos identificativos (los evangelista, con el tetramorfos). San Juan evangelista junto a San Lucas; Santiago el Mayor y San Felipe; San Pedro en cátedra (escrito en el libro: «ecce / nos / reli / [qvi] // mvs / omnia / [seqv / ti]») y San Pablo (en su libro, «ego / svm / mini / mvs 
// apos / tolo / qvi n / svm.»; correspondientes el evangelio de San Mateo [Mt 19, 27] y a la Primera Epístola de San Pablo a los Corintios [I Cor 15,9]), respectivamente, flanqueando el sagrario. San Bartolomé y San Andrés; y San Mateo y San Marcos. Imágenes: en el primer piso, San Luis obispo, San Juan Bautista, la Coronación de Nuestra Señora, Santiago el Mayor y Santa María Magdalena. Y en el ático, San Miguel arcángel luchando contra el demonio, San Pablo, Santiago el Menor y San Miguel con la maqueta de la Iglesia. El grupo de la Transfiguración del ático es de comienzos del siglo XVIII.

Para el grupo de la Coronación de Virgen, dispuesto en el cuerpo de gloria del retablo, empleó Castro el mismo modelo que Moure para uno de los relieves de los sitiales de la sillería de coro de la catedral de Lugo, como se ha visto. A Santa María Magdalena no la representó según el modelo barroco de una santa penitente sino como una cortesana, tipo de gran éxito en esta zona de la Península, como se constata en la producción de su discípulo, Pedro Sánchez de Agrela (encabezada por la titular del retablo mayor de la colegiata de Santa María Magdalena de la villa de Cangas del Narcea, de 1643). San Juan Bautista también es de concepción tradicional y no traduce aún el modelo innovador y de tanto éxito que Moure inventó para el monasterio de San Julián de Samos, pero que sí se verá en el retablo mayor de la colegiata de Cangas del Narcea, hecho por Sánchez de Agrela en 1643. Santiago el Mayor sigue el tipo convencional del peregrino. Acaso la mejor y más bonita sea la imagen de San Luis de Tolosa, con el hábito y cordón franciscano, revestido con la capa pluvial, la mitra y el báculo con el manutergio, en su calidad de obispo de Toulouse.

Estilísticamente, son imágenes caracterizadas por un leve movimiento corporal. Las telas anuncian la técnica del naturalismo barroco, con una multiplicación y movimiento de los pliegues que incluso llegan a quebrarse en algunas partes. Aunque las figuras son poco expresivas, se empiezan a abandonar el concepto de estatua cerrada y la impasibilidad de los semblantes. Los rostros están definidos por una nariz recta, ojos almendrados y mirada perdida. Los cabellos y las barbas están compuestos por mechones tratados con un afectado detalle.

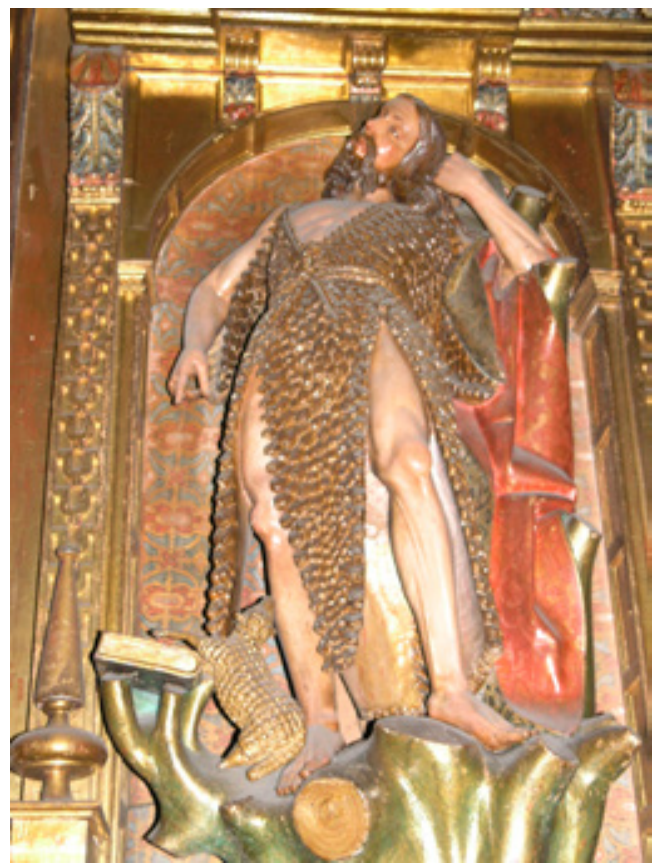

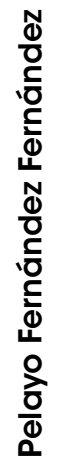

Fig. 18. Pedro Sánchez de Agrela, San Juan Bautista, h. 1643, retablo mayor, colegiata de Santa María Magdalena, Cangas del Narcea

El retablo original con sus imágenes, como aquí lo hemos descrito, fue dorado entre 1640-1645 por Pedro Díaz de Villabrille y Mon (San Martín de Oscos, Asturias, h. 1610-1669)50, asistido por los oficiales Juan de Santalla y Baltasar Rey. En la Visita del 24 de junio 1641, se dice que el retablo se está pintando y que por falta de dinero se autorizó tomar 2.200 reales a censo y sobre él, cargar los bienes de la fábrica. Por entonces, la obra no estaba muy avanzada, aclarándose que tardarán mucho tiempo en terminarla. El 11 de julio de 1641, comenzaron los pagos a los pintores, entregando el licenciado Ron 2.189 reales; el 3 de mayo de 1642 se dieron a Pedro Díaz 2.423 reales y una «anega» (fanega) de centeno que valía 13 reales; y el 16 de julio de 1643, se le pagaron otros 176. La última cuenta se hizo efectiva el 30 de mayo de 1645, cuando se libraron 1.483 reales, una vez terminada la obra ${ }^{51}$. Todas las imágenes labradas por Castro están doradas y estofadas con motivos vegetales (flores de lis y roleos) a punta de pincel. Los cabellos de algunas imágenes (la Magdalena y las dos del arcángel San Miguel) están dorados, y la encarnación es mate. 
Pero el retablo, tal como hoy lo vemos, es el resultado de unos añadidos y una nueva policromía efectuada en 1795 (fig. 13). Los añadidos fueron hechos entre 1771-1773 por José Fagín, como se ha dicho. Este maestro diseñó las cuatro hornacinas del primer piso, por encima del banco: las extremas trilobuladas y el resto, de medio punto sobre dinteles, estructuradas con ocho columnas abalaustradas. Las cuatro centrales, con cabezas de ángeles y colgantes en los tercios inferiores, nudos vegetales, y las partes superiores estriadas; las laterales, abalaustradas y divididas en dos partes: las inferiores con colgantes vegetales y las superiores estriadas. Las ménsulas son vegetales y se complementan con cabezas de querubines. En estas hornacinas están las imágenes de Santa Bárbara, San Matías, San José con el Niño y San Roque. Del mismo modo, Fagín amplio los relieves de los Apóstoles y Evangelistas del banco original de Juan de Castro, que eran de medio talle. Suyos son las partes inferiores de dichos relieves, así como el busto de Dios Padre del remate.

El frontal de la mesa del altar y las dos credencias se realizaron entre 1775-1776, cuando José Fajín transformó el retablo. Su policromía marmoleada es de finales del siglo XVIII, acaso de 1795, año que figura en la inscripción pintada en el sotabanco del retablo.

Panel izquierdo:

Pintose, Y dorose, Año / de 1795, Siendo Abad / DESTA COLE / GIATA [FLORÓN].

Panel derecho:

D," IVAN, ANTONIO, GR.A; / MARTINEZZ, \& [FLORÓN].

En las cuentas de ese año figuran 2.763 reales librados a los pintores por terminar de pintar el retablo, el Crucifijo de la sacristía y los nichos sobre la puerta de ingreso a esta. A nuestro entender, lo que se policromó de nuevo fue el sotabanco, el frontal de altar, las credencias y la parte inferior de los relieves que están marmoleados, según el gusto y estilo del momento. En el anonimato queda el maestro que lo llevó a cabo, aunque es probable que se tratara de Blas Fernández Castelao (documentado en 1763-1811), vecino de la villa de San Martín de Oscos que ya había trabajado otras obras en la colegiata ${ }^{52}$.
El retablo fue restaurado en 1992 por la Escuela de Artes y Oficios de Madrid ${ }^{53}$.

\section{3.- Retablo de Nuestra Señora del Rosario, templo parroquial de Santa María de Cecos (Ibias)}

Tras su estancia en la villa de Grandas, Juan de Castro pasó a la de Cecos, seguramente para trabajar para los Ron, linaje hegemónico en este concejo del extremo suroccidental de Asturias, en la cuenta alta del río Navia ${ }^{54}$. En la iglesia parroquial de Santa María hizo el retablo de Nuestra Señora del Rosario (190 cm, aprox.). No conserva la imagen titular, pero su primera advocación fue inequívocamente la de Nuestra Señora del Rosario, como dice el rótulo del relieve del banco; «regina, sacratissimi - rosari, ora pro nobis», cuya devoción fue potenciada por los dominicos, cuyo escudo preside el remate del retablo, y está presente en la efigie de Santo Domingo de Guzmán pintada en el banco. Ramallo destaca la fina talla de los ángeles y del relieve de La Virgen de la leche (fig. 14) $)^{55}$.

En el inventario de alhajas de la parroquia de Cecos, hecho el 12 de noviembre de 1764, se enumeran las imágenes desaparecidas: una Nuestra Señora del Rosario de vestir en la hornacina principal, y las de Santa Isabel y San Bartolomé, en las laterales. También tenía una custodia y un frontal de madera pintado ${ }^{56}$.

Aunque sin documentar, dos razones permiten vincular este retablo con Juan de Castro y su taller: el asentamiento del escultor en Cecos entre 1631-1633, seguramente para trabajar en el alhajamiento de la iglesia parroquial, pero sobre todo la estilística. Los elementos arquitectónicos son similares a los del retablo de Grandas de Salime: columnas de orden corintio, con el mismo tipo de capitel: las centrales, con los fustes torsos, y las laterales, estriadas, todas ellas con el tercio inferior estriado en sentido contrario al del giro del resto del fuste. Asimismo, los querubines del friso (originalmente, tres) son una imitación de los de aquel retablo. Lo más destacado es el sentido enviajado de la calle central, lo que descubre una disposición perspectiva original en el fondo de una capilla. No lo es menos el remate, compuesto por dos frontones: uno, triangular y escotado en su centro que hace de base y otro curvo de menor 
tamaño, de caprichosa concepción manierista. Soporta este, dos relieves de ángeles con cálices, que flanquearían un Crucificado, hoy día desparecido; se trata de un motivo iconográfico muy conocido: la Santa Sangre de la Redención. Finalmente, las bolas y pirámides clasicistas completan la arquitectura del ático. Las ménsulas son vegetales, en forma de sencillas hojas de alcachofa. En época indeterminada fue modificado, elevando el alzado, mediante la introducción de un dado muy basto, a modo de epistilo, en la calle central, que modifica la proporción original. Originalmente, también tenía una custodia y un frontal pintado.

La imaginería original estaba compuesta por Santa Isabel (en la calle lateral izquierda, "s. "ta isabel»), Nuestra Señora del Rosario y San Bartolomé ( «s. "bartolome»). En cambio, hoy día alberga las de San Roque, moderna, y Santo de época medieval, en cuya peana se lee «S. Joseph». El banco muestra el relieve ovalado de La Virgen de la Leche (25 x $49 \mathrm{~cm}$, aproximadamente). Castro da muestras aquí de una gran delicadeza expresiva y elegancia formal a base de unos pliegues curvos, bastante movidos y de gran efecto plástico. El semblante de Nuestra Señora es parecido al de las imágenes del retablo de Grandas de Salime.

La policromía del retablo también es de la época, con abundancia de dorados. El relieve de la Virgen de la leche está dorado, policromado y estofado, y la encarnación es mate. Los medallones pintados del banco en las calles laterales del banco que representan a Santo Domingo de Guzmán ("S. nto do [mingo]»; a la izquierda) y San Francisco de Asís («s." francisco»; a la derecha) son de factura ingenua.

\section{4.- Retablo de la Virgen de la Esperanza, en la capilla de Malneira (Grandas de Salime)}

Este retablo $(214 \mathrm{~cm}$, de anchura) de hacia 1631-1633 es una réplica del retablo anterior, pero sin el capricho de mostrar enviajada la calle central. Como novedad, la parte central del banco presenta una corona en relieve entre perinolas y sencillos cartuchos vegetales, alusión simbólica a la Reina de los Cielos (fig. 15).

En la hornacina central, hoy se venera una imagen de la Inmaculada (moderna) y en las calles laterales otras dos adaptadas, posteriormen- te, a la moda de las imágenes de vestir. La de nuestra izquierda es un Niño Jesús, del tiempo del retablo, posiblemente el de la imagen titular del retablo, hoy perdida.

Se conserva en blanco, siendo restaurado y rehecho recientemente.

\section{Continuidad del taller de Juan de Castro}

La actividad y el taller de Juan de Castro fueron continuados por su discípulo y yerno, Pedro Sánchez de Agrela que, tras a su colega Luis Fernández de la Vega (Llantones, Gijón, 1601-Oviedo, 1675), fue el retablista e imaginero más activo y capacitado del primer barroco en Asturias.

Nació en San Pedro de Mor (conceyo de Alfoz, Mariña Central de Lugo), diócesis de Mondoñedo, hacia 1610, y falleció de muerte repentina en el puerto de Cudillero (Asturias), el 6 de agosto de 1661, mientras trabajaba el monumental retablo mayor del templo parroquial de San Pedro. El primer testimonio de su presencia en Asturias es su actividad en la labra del retablo mayor de la colegiata de San Salvador de Grandas de Salime como oficial de Juan de Castro en 1630. Muerto ya Juan de Castro, en 1637, contrajo matrimonio con Francisca de Castro, hija de su maestro y de Catalina Alonso, en la villa de Cecos, donde residían los castro desde 1631-163357.

Tras breves estancias en Pesoz y Bullaso (Illano), hacia 1642-1643 se avecindó definitivamente en la villa de Cangas de Tineo para trabajar el retablo mayor de la colegiata de Santa María Magdalena, fundada por don Fernando de Valdés Llano, arzobispo de Granada y Presidente del Consejo de Castilla, y aquí mantuvo un importante taller desde el que controló toda la actividad escultórica y retablística de la zona suroccidental asturiana, convirtiendo a Cangas en la capital artística de toda aquella comarca.

Entre sus clientes se encontraban las órdenes religiosas (principalmente, los monasterios de Corias, Obona, Santa María de la Vega, Santo Domingo y San Francisco de Oviedo, y Encarnación de la villa de Cangas), la nobleza local (Ron, Queipo de Llano, Flórez, Sierra Pambley y Cienfuegos), canónigos, algún prelado de la diócesis, como don Bernardo Caballero de Paredes, uno 
de sus principales y más cualificados clientes, y las parroquias.

Fructíferas fueron las mancomunidades que estableció con Fernández de la Vega (cada uno en su respectivo oficio: Sánchez de Agrela como arquitecto de retablos y Fernández de la Vega como escultor). Juntó a él realizó en 1645, el desaparecido retablo mayor del santuario de $\mathrm{Ca}$ rrasconte (Babia-Laciana, León) donde también colaboró el ensamblador ovetense Alonso Carreño (documentado en 1622-1650); en 1650, en los retablos colaterales del convento de Agustinas Recoletas (hoy, de padres carmelitas) de Medina del Campo (Valladolid), financiados por el obispo don Bernardo Caballero de Paredes, y en 1652, el retablo de la capilla de San Martín de Tours de la catedral de Oviedo, para el canónigo don Martín de la Vara Reyero.

Cultivó principalmente la estatuaria religiosa y aunque esencialmente trabajó la madera (imágenes, relieves, retablos y escudos) también se le conocen algunos trabajos en piedra (imágenes, retratos orantes y escudos). Sus trabajos más destacados son el retablo mayor de la colegiata de Cangas, el ensamblaje del retablo de la capilla de Malleza en la colegiata de Salas y las obras hechas en mancomunidad con Fernández de la Vega.

En el arte de Sánchez de Agrela se percibe una evolución estilística desde el tardomanierismo de sus primeros trabajos (hasta su asentamiento en Cangas, 1634-1643); pasando por un estilo de transición que coincide con el descubrimiento de los tipos iconográficos y estilo del naturalismo castellano de Gregorio Fernández (1645-1650), su continuidad en el naturalismo entre 16501655 y su evolución hacia el naturalismo barroco en el último lustro de su vida. Fue un artista que supo combinar los modelos de tradición gallega, asimilados de la obra de Francisco de Moure a través de su maestro, Juan de Castro (como la Coronación de la Virgen de la sillería de la catedral de Lugo y San Juan Bautista hecho por Moure para el monasterio de Samos), con los naturalistas, sin duda aprendidos con Fernández de la Vega (San José con el Niño o Inmaculada Concepción). Sus tipos físicos recuerdan en gran medida los empleados por Moure, como son las cabezas de pequeño tamaño, el modo de tallar los cabellos y las barbas, el canon ligeramente alargado de las figuras y la fisonomía de los rostros, así como el corte profundo y en grandes planos de los pliegues ${ }^{58}$.

Pedro Sánchez de Agrela dejó un importante taller ${ }^{59}$ que perpetuó su actividad, estilo y modelos hasta comienzos del último cuarto del siglo XVII, cuando se implantó en Cangas el estilo barroco decorativo y el retablo de orden salomóniCo, a raíz de la construcción del retablo mayor del monasterio benedictino de San Juan Bautista de Corias $^{60}$. Su taller instalado en la calle del Puente de la villa de Cangas fue heredado por Manuel de Ron y Llano (hacia 1645-1732).

En la iglesia de Santiago de Pesoz se conserva un grupo de la Coronación de la Virgen $(100 \mathrm{~cm}$, de altura; fig. 16) que imita el de la colegiata de Grandas. Este grupo proviene del retablo de la capilla Villaamil Illano, diseñado por Sánchez de Agrela y acaso labrado por algún oficial suyo en $1638^{61}$. Por su parte, el San Pablo de este mismo retablo (fig. 17) sigue el modelo que Francisco de Moure hizo para la iglesia de San Juan de Rairiz de Veiga (Orense) hacia 1615, con una túnica ceñida por una estrecha cinta y manto de pliegues amplios. La espada empuñada al frente mientras que con la otra mano sujeta las Sagradas Escrituras. Modelo que ya había sido empleado por Castro en el retablo de Grandas, como quedó dicho.

En el San Juan Bautista (fig. 18) del retablo mayor de la colegiata de Cangas del Narcea (1643), Sánchez de Agrela recurrió al modelo de anacoreta atento, escuchando la voz de Yahvé en el desierto, inventado por Francisco de Moure en la segunda década del siglo XVII para el monasterio de Samos y que tanto éxito tuvo en el noroeste peninsular durante ese siglo ${ }^{62}$, como se demuestra en la imagen de San Juan Bautista de la catedral de Astorga (1655-1660), una de las más felices y populares creaciones de Mateo de Prado (h. 1614-1677), donde exhibe su buen quehacer en el tratamiento anatómico y expresi$v^{63}$, o en la titular del retablo mayor del monasterio benedictino de San Juan Bautista de Corias, hecha por Pedro del Valle en 1677-167964.

Este modelo lo volvió a repetir Sánchez de Agrela en otras ocasiones, como en el santuario de Nuestra Señora de Miravalles (Aller, Asturias) ${ }^{65}$. 


\section{Conclusión}

Concluimos este artículo diciendo que el escultor Juan de Castro fue una figura relevante en el panorama escultórico local que difundió los modelos y el estilo maduro de Francisco de Moure por toda la zona suroccidental de Asturias. Pero a su vez supo evolucionar hacia cierto natu- ralismo barroco emanado de la obra de Gregorio Fernández, con una captación más realista de las actitudes de los personajes, una frontalidad en las figuras y un tratamiento más monumental, más duro y acartonado de los pliegues, como se ve en las imágenes del retablo mayor de la colegiata de San Salvador de Grandas de Salime. 


\section{APÉNDICE DOCUMENTAL}

\section{1637, marzo, 6. Cecos (Ibias, Asturias)}

Poder para obtener dispensa otorgado por el escultor Pedro Sánchez de Agrela, vecino de la villa de Cecos, para casarse con Francisca de Castro, hija del escultor Juan de Castro y de Catalina Alonso, su viuda.

AHA: ante Gómez Pérez Valledor, caja 13.447, fol. $s / n{ }^{\circ}$

«Poder de dispensa de Pedro de Agrela.

En la villa de Cecos, qoncejo de lbias, a seis días del mes de marco y mill y seiscientos y treynta y siete años, por ante my, escribano, y testigos, parecieron presentes: Pedro de Agrela, escultor, y Catalina Alonso, biuda que fue de Juan de Castro, como madre lexítima de Francisca de Castro, residentes en esta dicha billa de Cecos.

E dijeron que por quanto entre ellos estaba tratado y concertado hubiesen de contraher matrimonio, según horden de la Santa Madre Yglessia de Roma, entre los dichos Pedro de Agrela, escultor, y la dicha Francisca de Castro. Y por caussa de que entre los dichos contrayentes ay deuda de consanguinydad, tercio con quarto, hes necesario dispensa y gracia de su Santidad para el dicho efetoy para que se despache y trayga con la brebedad que se pueda, dijeron que por la bía, forma y manera que de derecho más hubiese lugar se obligaban y obligaron, entanbos juntos de mancomún, a boz de uno y cada uno, ynsólidum por el todo, renunciando como renunciaron las leyes de la mancomunidad, excursión y dibisión y la de Epístola del dibo Adriano de dar y pagar, que darán e pagarán Ilanamente sin contienda, ny figura de juycio para que les aga traher y despachar la bula y dispensa del dicho fiado de tercio con quarto y entregársela a su merded don Juan de Herera, chantre de la Santa Yglesia de Obiedo, becino de la ciudad de Oviedo, o a Pedro Buelta, becino de la billa de Ponferada, y a la persona que por ellos lo aya de aber, y es a saber: docientos reales de plata doble, más o menos lo que fuere concertado con uno de los susodichos al que está o su traslado signado se entregare, los quales dichos doscientos reales de dicha plata doble más o menos cantidad, quedaron de se los dar y pagar dentro de treynta días, como sean abisados por el tal curial que tiene en su poder dicha dispenssa y bula, puestos en una de las dos partes, en poder dellas después, hante qual se recomendare y obligare de la traher en dicha ciudad de Obiedo o Ponferada.

Y no cumpliendo el dicho placo ny ynbiando acer dicha paga y recibir la dicha dispenssa, pusieron condición que el tal despachante pueda a costa dellos y cada uno ynbiar una persona a la cobranza, con cuatrocientos reales de salario de cada un día que en ellos se ocupare y detubiere de yda, buelta y estada, por los quales salarios quieren ser executados como por el principal, debajo del derecho rato manente pato.

Para cuyo efeto, dieron su poder cumplido a las justicia de su Majestad y su fuero para que por todo rigor de derecho les compelan a ello, sea cumplidamente como si todo ello fuese pasado por sentencia difinitiba, sobre | fol v. que renunciaron las leyes en su favor. Y la dicha Catalina Alonso renunció las de los emperadores Justiniano Beleyano, partidas y Leyes de Toro y demás en este caso, y entanbos la que defiende la general renunciación. En fe de ello otorgaron la presente carta de obligación ante my, escribano, y por no saber firmar rogaron al licenciado Alonso Cadenas, firmó por ellos de su nombre, el que firmó su merced don Antonio de Ron y don Lope Núnez de Ron y don Josep de Uría y Baldés, becinos deste qoncejo y de Cangas y abadía de Bega de Santo Andrés, e yo escribano doy fee conozco los otorgantes dichos.

Alonso Cadenas [rubricado]. Pasó ante my, Gómez Pérez Valledor [rubricado].» 
NOTAS

'Agradecimientos: me gustaría mandar un sincero agradecimiento a don Jorge Cuesta Fernández, párroco presbítero que fue de Grandas de Salime y Pesoz, por su desinteresada ayuda, y a Javier González Santos, de la Universidad de Oviedo, por las observaciones y atenta corrección de este artículo.

Siglas AHA: Archivo Histórico de Asturias (Oviedo). AHDO: Archivo Histórico Diocesano de Oviedo / APCN: Archivo Parroquial de Cangas del Narcea / APGS: Archivo Parroquial de Grandas de Salime (Asturias). AEA: Archivo Español de Arte (Madrid). BIDEA / BRIDEA: Boletín del Instituto de Estudios Asturianos / Boletín del Real Instituto de Estudios Asturianos (Oviedo). BSAA: Boletín del Seminario de Estudios de Arte y Arqueología (Valladolid)

G. Ramallo Asensio, Escultura barroca en Asturias, Oviedo, IDEA, 1985, p. 257.

${ }^{2}$ P. Fernández Fernández, Actividades escultóricas en la zona suroccidental de Asturias durante los siglos XVII y XVIII: los talleres de Cangas y de Corias, Universidad de Oviedo (inédita), 2014, pp. 188-189.

${ }^{3}$ Ramallo, Escultura barroca, 1985, pp. 132-133.

${ }^{4}$ J. González Santos, Los comienzos de la escultura naturalista en Asturias (1575-1625). El legado artístico del arzobispo Valdés Salas y el escultor toresano Juan Ducete Díez, Oviedo, Consejería de Cultura del Principado de Asturias, 1997, p. 15.

${ }^{5}$ P. Pérez Costanti, Diccionario de artistas que florecieron en Galicia durante los siglos XVI y XVII, Santiago de Compostela, 1930 (reed. facsimilar: Santiago de Compostela, 1988), p. 100.

${ }^{6}$ En el lado del evangelio hay dos sepulcros bajo arcosolio. En el de la izquierda se lee: «[aq]ví iace el mui / noble y [i]lustre / caballero don / alonso de ron»; y en el de la derecha, "[aqvi ya] ce el muy nob / [leal i ilvstre caballe / ro don miguel anto / nio de ron]». En el muro de la epístola, otros dos arcosolios, dando frente a los primeros. El de la izquierda dice: «aqv[i] yace la mui noble / y [i]lustre señora d[oñ]a / ana bernardo de quirós»; y en el de la dere- cha: «aqu[i] yace la mu[i] noble / [i]lvstre señora d[oñ]a / beatriz miranda». En la enjuta, entre estos dos arcosolios se lee: «siendo pontífice [i]nocenzio xi y empera / dor leopol[do i] y rei de españa car / los ii [i] obispo de obiedo / d[o]n alonso antonio de san mar[tin] / y cu[r]a de esta parroqvia d[o]n mathias / gomez sobre / monte comiss. ${ }^{\circ} /$ año de / 1681 » (véase C. Miguel Vigil, Asturias monumental, epigráfica y diplomática, t. I, Oviedo, 1887 [reed. facsimilar: Oviedo, Consejería de Educación Cultura y Deportes del Principado de Asturias, 1987], pp. 393394; recogidas y transcritas también por J. Manzanares Rodríguez, "Contribución a la epigrafía asturiana», Archivum, I, Oviedo, Universidad de Oviedo, 1952, pp. 15-16).

${ }^{7}$ Ramallo, Escultura barroca, 1985 , pp. $180,197,199-201$ y 268 , figs. 29 , 54,57 y 77 .

${ }^{8}$ No cabe confundir a Juan de Castro con un homónimo que trabajó en Galicia a finales del siglo XVIII. En efecto, entre 1795 y 1797 junto al escultor lucense Manuel Luaces, realizó un retablo en piedra de San Froilán para la catedral de Lugo, destinado a la imagen del titular realizada por Francisco de Moure (M. Dolores Vila Jato, "Notas sobre el primitivo retablo de San Froilán de la catedral de Lugo», Boletín del Museo Provincial de Lugo, t. III, Lugo, 1987, p. 50). Tampoco con el pintor Juan de Castro, avecindado en 1598, en Huete (Cuenca), y que posiblemente, perteneciese a la familia del pintor Pedro de Castro, activo a mediados del siglo XV en la actual provincia de Cuenca (M. L. Rokiski Lázaro, «Datos documentales sobre la pintura conquense del siglo $X \mathrm{~V} \mid$ », AEA, t. LXIV, n. ${ }^{\circ} 253$, Madrid, 1991, p. 81). A esta información se suma otra, la de un Juan de Castro, mercader de Santiago de Compostela, que en 1623, afianzó la construcción del retablo de la cofradía del Corpo Santo en la iglesia de Santa María la Mayor de Pontevedra, realizado por Francisco de Dantas ( $M$. Gómez-Moreno, "Sobre Cornelis de Holanda», El Museo de Pontevedra, t. I, 1942, p. 126, y Aa. Vv., «Documentación artística de Santa María», El Museo de Pontevedra, tomo XLII, 1988, p. 222). También se han localizado a otros individuos con el apellido Castro en la provincia de Lugo en el siglo XVIII:
Gregorio de Castro, de oficio escultor, documentado en 1707, y Agustín de Castro, hijo de Domingo González de Castro, documentado en 1701 (M. T. García Campello, «Lugo y su entorno: los artistas del siglo XVIII y su obra a través de los protocolos notariales», Boletín del Museo Provincial de Lugo, t. XII, Lugo, 2005, pp. 9-86)

9 Pérez Costanti, Diccionario, p. 100. También en Miguel Taín Guzmán, «Clasicismo y barroco en tierras mindonienses», Revista de Estudios Mindonienses, n. ${ }^{\circ}$ 15, Mondoñedo, 1999, p. 471.

10 Ramallo, Escultura barroca, 1985, pp. 133-135, figs. 11-12.

${ }^{11}$ Fernández Fernández, Actividades escultóricas, 2014, pp. 197-215.

12 AHA: ante Antonio López, caja 13.494, fols. 36-37 (ápud Fernández Fernández, Actividades escultóricas, pp. 197-198; Ap. doc. n. ${ }^{\circ}$ 52).

${ }^{13} \mathrm{AHA}$ : ante Gómez Pérez Valledor, caja 13.447, fol. s/n. ${ }^{\circ}$ (ápud Fernández Fernández, Actividades escultóricas, p. 198; Ap. doc. n. $\left.{ }^{\circ} 35\right)$.

${ }^{14}$ APCN: Libro de difuntos de la colegiata de Cangas del Narcea (16001698), fol. $125 v^{\circ}$ (ápud Fernández Fernández, Actividades escultóricas, p. 222; Ap. doc. n. $\left.{ }^{\circ} 84\right)$.

${ }^{15}$ APGS: Libro de bautismos de la colegiata de San Salvador de Grandas de Salime (1588-1787), fol. $151 \mathrm{v}$ (ápud Fernández Fernández, Actividades escultóricas, p. 198; Ap. doc. n. ${ }^{\circ} 32$ ).

${ }^{16}$ Fernández Fernández, Actividades escultóricas, pp. 525-529; Ap. doc. n. ${ }^{\circ} 153$

${ }^{17}$ AHDO: Libro de difuntos de la iglesia de Santa María de Cecos, caja 24.1.1-2, fol. $11 \mathrm{v}$ (ápud Fernández Fernández, Actividades escultóricas, $\mathrm{p}$. 198; Ap. doc. n. ${ }^{\circ} 33$ ).

18 Ramallo, Escultura barroca, 1985 , p. 258

${ }^{19}$ AHA: ante Diego García de Quirós, caja 13.476 , fol. s/n. (ápud Fernández Fernández, Actividades escultóricas, p. 365; Ap. doc. n. ${ }^{\circ} 88$ ). El hecho de ser licenciado y artista, lo relaciona con otros licenciados asturianos que también trabajaron la escultura, caso de Alonso Fernández de la Vega († 1700), hijo del escultor Luis Fernández de la 
Vega (Llantones, Gijón, 1601-Oviedo, 1675), el principal representante del naturalismo barroco castellano en Asturias y alumno de Gregorio Fernández en Valladolid, y el licenciado Antonio de Ron († 1704), hermano del ensamblador Manuel de Ron y Llano (Cangas de Tineo, h. 1645-1732), casado con una nieta de Juan de Castro, que colaboró con él en algunos trabajos para la iglesia de San Juan Bautista, en Vega de Rengos, concejo de Cangas del Narcea. Para Alonso de la Vega y Antonio de Ron, vid. Ramallo, Escultura barroca, pp. 232-234, y Fernández Fernández, Actividades escultóricas, p. 719.

20 Ramallo, Escultura barroca, 1985, p. 258.

${ }^{21}$ Ibídem.

${ }^{22}$ APCN: Libro de bautismos de la colegiata de Cangas del Narcea, fols. 13 y $24 v$ (Fernández Fernández, Actividades escultóricas, p. 223; Ap. doc. n. $\left.{ }^{\circ} 61\right)$.

${ }^{23}$ E. Marcos Vallaure, "Juan Alonso Villabrille y Ron, escultor asturiano», BSAA, XXXVI, Valladolid, Universidad de Valladolid, 1970, pp. 154-155.

${ }^{24}$ Ensamblador activo en la villa de Corias entre 1679 y 1724 . Suministró obra parar todo el suroccidente de Asturias y la actual provincia de León (Santiago Millas y Cubillos del Sil). Sobre este maestros véase: F. Llamazares Rodríguez, El retablo barroco en la provincia de León, León, Universidad de León, 1991, p. 249, Íd., Fuentes documentales para el arte barroco en la provincia de León. Ensambladores, escultores y pintores, León, Universidad de León, 2008, pp. 119; 497 J. M. González Álvarez, "San Cristóbal de Entreviñas», La Maniega, n. ${ }^{\circ} 138$, Cangas del Narcea, 2004, p. 27. Fernández Fernández, Actividades escultóricas, p. 223; Ap. doc. n. os 191-218.

${ }^{25}$ Fernández Fernández, «El retablo mayor del antiguo monasterio benedictino de San Juan Bautista de Corias (Cangas del Narcea, Asturias), primicia del barroco decorativo en la zona noroccidental de España», Liño, n. ${ }^{\circ} 19$, Oviedo, Universidad de Oviedo, 2013, pp. 23-40.

${ }^{26}$ APCN: Libro de difuntos de la colegiata de Cangas del Narcea, fol. 5 (ápud Fernández Fernández, Activida- des escultóricas, p. 223; Ap. doc. n. ${ }^{\circ}$ 87).

${ }^{27}$ Conocemos algunos de los mancebos contratados por Francisco de Moure: Juan Rodríguez, Blas Fernández y Domingo Fernández, vecinos de Orense. Tampoco figura entre los colaboradores tomados por Moure en Lugo para realizar la sillería de coro de la catedral. Entre ellos están Juan Darmas, Bautista de Marín, Francisco López, Juan de Flórez, Alonso Fernández de Rubías, Francisco Gómez, Marcos Fernández y Jácome de Carnín (M. D. Vila Jato, Francisco de Moure, Santiago, Xunta de Galicia, 1991, pp. 12-17). También se refiere a los colaboradores de Francisco de Moure Narciso Peinado (Lugo monumentaly artístico, Lugo, 1951, pp. 67-68).

${ }^{28}$ Sobre Francisco de Moure, vid. entre otros: Costanti, Diccionario, pp. 398-402 y 586-590; Peinado, Lugo monumental y artístico, 1951, pp. 6768; M. E. Gómez-Moreno, Escultura del siglo XVII, "Ars Hispaniae, XVI», Madrid, Plus-Ultra, 1963, pp. 124-126, figs. 101-105; Vila Jato, «Nuevas esculturas de Francisco de Moure», Boletín Auriense, t. 10, Orense, Museo Arqueológico Provincial de Orense, 1980, pp. 217-226; Íd., Francisco de Moure, 1991; Íd., «La primera generación de escultura barroca: Gregorio Fernández y Francisco de Moure», en X. FilgueiraValverde, La escultura gallega: el centenario de Francisco Asorey, Santiago de Compostela, fundación A. Brañas, 1991, pp. 55-65; I. Gutiérrez Pastor, "Sobre Francisco de Moure y el retablo de Santa María de Beade (Ourense)», El Museo de Pontevedra, t. XLVII, 1993, pp. 123-133; Íd., "Sobre Francisco de Moure y el retablo de Santa María de Beade (Orense): una estatua de Caballero de Malta semiarrodillado», AEA, t. LXVII, Madrid, 1994, p. 119; J. J. Martín González, Escultura barroca en España, Madrid, Eds. Cátedra, 1998, pp. 282-285 y M. López Calderón, «La obra del escultor y arquitecto Francisco de Moure en San Xulián de Samos», en San Xulián de Samos historia y arte de un monasterio. Opus monasticorum iii, Xunta de Galicia, 2008, pp. 193-203.

${ }^{29}$ Vila Jato, Francisco de Moure, 1991, pp. 48-54. Todas las fotografías incluidas en el texto de las obras de de
Francisco de Moure han sido tomadas de esta obra.
${ }^{30}$ Ídem, p. 119.
31 Ídem, pp. 73-74.
32 Fernández Fernández, Actividades escultóricas, cat. R. 1 de Pedro Sánchez de Agrela, pp. 245-247; Ap. doc. n. ${ }^{\circ} 34$.

${ }^{33}$ Pérez Costanti, Diccionario, p. 100.

${ }^{34}$ San Cristóbal Sebastián, La catedral de Mondoñedo, 1984, p. 52.

${ }^{35}$ E. Cal Pardo, "Catedral de la Asunción de Mondoñedo», en Las Catedrales de Galicia, León, Edilesa, 2005, p. 217.

${ }^{36} \mathrm{El}$ resto de las esculturas son de distintos periodos: Santa Ana enseñando a leer a la Virgen niña es de procedencia inglesa y fue traída con antes de 1555 por el clérigo Alonso Ares Mourelle. San Sebastián y Santa Bárbara, del siglo XVIII; un Santo Apóstol del XVII y una Santa Catalina del XVI (Cal Pardo, «Catedral de Mondoñedo», p. 217.

${ }^{37}$ El maestro de cantería montañés Ibáñez Pacheco (a quien se debe la obra del claustro de la catedral de Mondoñedo) fue el encargado de construir la colegiata de Cangas del Narcea; para ella también diseñó, doce años más, los nichos funerarios del arzobispo don Fernando de Valdés y Llano y del obispo de Coria don Juan Queipo de Llano y Navia en la colegiata de Cangas del Narcea (González Santos, «La iglesia de Santa María Magdalena de Cangas del Narcea: puntualizaciones histórico-artísticas a un edificio singular del barroco asturiano», La Maniega, n. ${ }^{\circ}$ 70, Cangas del Narcea, 1992, p. x, e Íd., "Aristócratas en vanguardia: las fundaciones y empresas artísticas de los Queipo de Llano en Asturias en el siglo XVII», en $M$. Á. Faya Díaz (coordinadora), Las ciudades españolas en la Edad Moderna: oligarquías urbanas y gobierno municipal, Oviedo, Ediciones KRK, 2014, pp. 386388, figs. 13 y 25, láms. XVIII y XXVIII.

${ }^{38}$ San Cristóbal Sebastián, La catedral de Mondoñedo, 1984, p. 54.

${ }^{39}$ Sobre la colegiata de Grandas, vid., entre otros, Miguel Vigil, Asturias monumental, epigráfica y diplomática, vol. I, 1887. p. 395; J. M. MéndezValledor y Guzmán, «Grandas de 
Salime», en O. Bellmunt y Traver y F. Canella Secades, Asturias, t. III, Gijón, 1900 (reed. facsimilar: Gijón, Silverio Cañada, 1987), pp. 91-92; A. de Llano Roza de Ampudia, Bellezas de Asturias de oriente a occidente, Oviedo, 1928, p. 490; Vv. Aa., «Grandas de Salime, San Salvador de», en Gran Enciclopedia Asturiana, vol. 8, Gijón, 1970, p. 41; P. González Lafita y R. M. García Quirós, «Zona occidental», Liño, n. ${ }^{\circ}$ 2, Oviedo, Universidad de Oviedo, 1981, pp. 146148, y J. González Santos, «Templo parroquial de San Salvador de Grandas. Capilla de la Inmaculada en Folgosa. Templo parroquial de Santiago de Pezós», en Grandas de Salime. Pesoz, «Asturias concejo a concejo, vol. 17», Oviedo, RIDEA, 2010, pp. 131-132.

${ }^{40} \mathrm{P}$. Madoz, Diccionario geográfico-estadístico-histórico, 1845-1850 (reed. moderna: Asturias, Valladolid, 1985, p. 193).

${ }^{41}$ Según Ramallo «la parte añadida es mucho más torpe, tanto en arquitectura como en imaginería, señalando la actuación de cualquier tallista local que no supo adecuarse a la dignidad de lo ya existente» (Escultura barroca, 1985, p. 134).

${ }^{42}$ Las primeras referencias sobre Fagín las aportó Ramallo, quien documentó su intervención en el retablo de San Antonio de Padua de la colegiata de Grandas de Salime (Ramallo, Escultura barroca, 1985, pp. 134 y 580). Posteriormente, Alberto Fernández Suárez y José Antonio Ron Tejedo documentaron su intervención en el retablo mayor de la iglesia de Santa María Magdalena en Marentes (Ibias) en 1764 (A. Fernández Suárez y J. A. Ron Tejedo, El patrimonio artístico del concejo de Ibias, Oviedo, 1997, p. 55)

${ }^{43}$ J. González Santos, «Templo parroquial de San Salvador de Grandas. Capilla de la Inmaculada en Folgosa. Templo parroquial de Santiago de Pezós», en Grandas de Salime. Pesoz, 2010, pp. 131-132. También se han referido al retablo de Grandas, M. Berenguer, Rutas de Asturias, Oviedo, 1968, p. 132; Ramallo, Guía de Asturias, León, 1979, p. 170; Íd., «El barroco», en Enciclopedia Temática de Asturias, vol. 5, Gijón, 1981, p. 50.
${ }^{44}$ APGS: Libro de fábrica de la colegiata de Grandas, fol. 95v (ápud Fernández Fernández, Actividades escultóricas, p. 208; Ap. doc. n. ${ }^{\circ} 30$ ).

${ }^{45}$ idem, fol. $101 \mathrm{v}$.

${ }^{46}$ ídem, fol. 106.

${ }^{47}$ Ídem, fol. $107 \mathrm{v}$.

${ }^{48}$ Idem, fols. $109 \mathrm{v}-111 \mathrm{v}$.

${ }^{49}$ Idem, fols. 117, 120-121, $125 \mathrm{v}$, $134,137 v, 149,206 v$ y $220 v$.

${ }^{50}$ González Santos, «Templo parroquial de San Salvador de Grandas. Capilla de la Inmaculada en Folgosa. Templo parroquial de Santiago de Pezós», en Grandas de Salime. Pesoz, 2010, p. 132.

${ }^{51}$ APGS: Libro de fábrica de la colegiata de San Salvador de la villa de Grandas de Salime (1607-1644), fols. 95v, 101v, 106, 107, 109-111, 117, 125, 134, 137, 149, 206 y 220 (transcrito en Fernández Fernández, Actividades escultóricas, Ap. doc. n. ${ }^{\circ} 31$ )

${ }^{52}$ Previamente, en 1763 la colegiata de Grandas de Salime pagó «ciento y diez reales que el pintor don Blas Fernández Castelao, vecino de San Martín de Oscos, llevó por dorar enteramente al óleo la cruz, bola y veleta que se puso por encima del chapitel de la torre de esta yglesia, manifestó recibo de dicho pintor con fecha de diez de abril de 1762 [...]》 (APGS: Libro de fábrica de la colegiata de San Salvador de Grandas de Salime, fol. 45; ápud Fernández Fernández, Actividades escultóricas, 2014, p. 951); «[...] ochenta reales bellón que pagó a don Blas Fernández Castelao, vezino de San Martín de Oscos, por la encarnación y pintura que echó a las efigies de Jesús Nazareno y Soledad, y a la cruz del primero, por cuya obra llevó la expresada cantidad y dio recibo que manifestó este mayordomo con fecha del nueve de abril de 1665 [...]» (APGS: Ídem, fol. 57; ápud Fernández Fernández, Actividades escultóricas, 2014, p. 951). $Y$ «doscientos y ocho reales que se pagaron a don Blas Fernández Castelao, vecino de la villa y parroquia de San Martín de Oscos, de oficio pintor, dorador, por el travajo que tuvo y materiales que gastó en pintar y dorar las dos ymágines del Salvador, Nuestra Señora del Carmen, destinadas para las procesiones» (APGS: Ídem, fol. 249; ápud Fernández Fernández, Actividades escultóricas, 2014, p. 951).

${ }^{53}$ Consejería de Cultura del Principado de Asturias: Inventario de Bienes Muebles de la Iglesia Católica, caja 94, ficha 10.016

${ }^{54}$ Según José Manuel Trelles y Villademoros, el miembro más antiguo de esta familia fue doña Constanza de Ron, esposa de don Fernando Álvarez Villaamil. Fueron los Ron una familia muy linajuda, de mucho señorío y con gran influencia en el concejo de lbias. Los miembros más destacados de ella fueron don Pedro Díaz de Ibias y Ron, gran prior de la orden de San Juan, que murió en la batalla de Aljubarrota en 1385. Conservan los señores de esta casa muchos bienes en Asturias y muchos señoríos y vasallajes (J. M. Trelles y Villademoros, Asturias Ilustrada. Primitivo origen de la nobleza de España, su antigüedad, clases y diferencias, 2. ${ }^{\text {a }}$ ed., Madrid, 1760, t. IV, pp. 176-177).

55 Ramallo, Escultura barroca, 1985, p. 580. También se han referido a este retablo, Fernández Suárez, «Patrimonio monumental», en Cangas del Narcea. Ibias. Degaña, "Asturias concejo a concejo», vol. 3, 1994, p. 197, y Fernández Suárez y Ron Tejedo, El patrimonio artístico del concejo de Ibias, 1998 , p. 32.

${ }^{56}$ «En el altar de Nuestra Señora del Rosario, su ymagen de vestido, al lado derecho la de Santa Isabel y la de San Bartolomé, y en una custodia que tiene con su llave y cerradura tres alhajas de plata en una caja de estaño, más frontal de madera pintado, ara, atril y su retablo dorado.» (AHDO: Libro de fábrica de la iglesia de Santa María de Cecos, caja 24.1.11, fols. 167-168).

${ }^{57} \mathrm{AHA}$ : ante Gómez Pérez Valledor, caja 13.447, fol. s/n. ${ }^{\circ}$ Ap. doc. n. ${ }^{\circ} 1$ (ápud Fernández Fernández, Actividades escultóricas, p. 198; Ap. doc. n. ${ }^{\circ}$ 35).

${ }^{58}$ Sobre Sánchez de Agrela, vid. F. A. Díez González, Memoria del antiguo y patriarcal concejo de Laciana, 1946 (reed.: León, Eds. Leonesas, 1985), p. 56; F. Mayán Fernández, «El santuario de Nuestra Señora de Carrasconte. Notas históricas», Archivos Leoneses, n. III, León, 1949, p. 45; F. Bouza-Brey, «Los altares del crucero de la catedral de 
Oviedo y otras noticias sobre el barroco en Asturias», BIDEA, n. ${ }^{\circ} 20$, Oviedo, 1953, pp. 526-527; E. Marcos Vallaure, "Juan Alonso Villabrille y Ron, escultor asturiano», BSAA, XXXVI, Valladolid, Universidad de Valladolid, 1970, pp. 154-155; Ramallo, Escultura barroca en Asturias, 1985, pp. 257-276, figs. 116141, y Fernández Fernández, Actividades escultóricas, 2014, pp. 219-361.

${ }^{59}$ En su taller figuran su hijo, Juan Sánchez de Agrela y Castro (16451687), su hermano, Antonio Sánchez de Agrela (doc. en 1650-1666), Juan Fernández (Corias, Cangas del Narcea, doc. en 1653-1662), Juan Menéndez de Tablado (Corias, doc. en 1653-1664), los hermanos Rodríguez Queipo, Francisco (h. 1630-1689) y Domingo (doc. en 1662-1671), naturales de Centenales (Ibias), Juan López Bahamonde (Mondoñedo, doc. en 1662-¿Lugo?, post 1703) y Bernabé López Bahamonde (vecino de Lugo, doc. en 1686).

${ }^{60}$ Fernández Fernández, «El retablo mayor del antiguo monasterio benedictino de San Juan Bautista de
Corias (Cangas del Narcea, Asturias), primicia del barroco decorativo en la zona noroccidental de España», Liño, n. ${ }^{\circ}$ 19, Oviedo, Universidad de Oviedo, 2013, pp. 23-40.

61 Ramallo, Escultura barroca, 1985, pp. $134-135$ y 591, fig. 13. González Santos, «El templo parroquial de San Salvador de Grandas. Capilla de la Inmaculada en Folgosa. Templo parroquial de Santiago de Pezós», en Grandas de Salime. Pesoz, "Asturias concejo a concejo», vol. 17, 2010, p. 150; Fernández Fernández, Actividades escultóricas, cat. I. 8, p. 317.

${ }^{62}$ Francisco de Moure concertó con el monasterio de Samos la hechura de cinco retablos. El mayor fue sustituido a finales del siglo XVIII por el actual, de José Ferreiro. De los otros cuatro retablos, solo dos han llegado íntegros. Están dedicados a la Virgen, Santa Catalina, San Benito y San Juan. Sobre estos retablos, vid. Costanti, Diccionario, pp. 398-402 y 586-590; Peinado, Lugo monumental y artístico, 1951, pp. 6768; Gómez-Moreno, Escultura del siglo
XVII, 1963, pp. 124-126, figs. 101-105; Vila Jato, «Nuevas esculturas de Francisco de Moure», Boletín Auriense, t. 10, Museo Arqueológico provincial de Orense, 1980, pp. 217-226; Íd., Francisco de Moure, 1991, p. 82; Íd., "La primera generación de escultura barroca: Gregorio Fernández y Francisco de Moure», separata de Filgueira-Valverde, La escultura gallega: el centenario de Francisco Asorey, Santiago de Compostela, Fundación A. Brañas, 1991, pp. 63-64; Martín González, Escultura barroca en España 1600-1770, 1998, p. 283.

${ }^{63}$ Llamazares, «En torno al escultor Mateo de Prado», Tierras de León, n. ${ }^{\circ}$ 73, León, 1988; Íd., El retablo barroco en la provincia de León, Universidad de León, 1991, p. 257; Íd., Fuentes documentales para el arte barroco en la provincia de León, 2008, pp. 371-372.

${ }^{64}$ Fernández Fernández, «art. cit.», p. 34.

65 Ramallo, Escultura barroca, 1985, p. 276, y Fernández Fernández, Actividades escultóricas, 2014, cat. I. 11, pp. 320-321. 


\section{REFERENCIAS}

Berenguer, Magín. 1968. Ruta de Asturias: guía turística y monumental. Oviedo: Diputación Provincial.

Bouza-Brey, Fermín. 1953. "Los altares del crucero de la catedral de Oviedo y otras noticias sobre el barroco en Asturias." BIDEA 20: 526527.

Cal Pardo, Enrique. 2005. Las Catedrales de Galicia. León: Edilesa.

Fernández Fernández, Pelayo. 2013. “El retablo mayor del antiguo monasterio benedictino de San Juan Bautista de Corias (Cangas del Narcea, Asturias), primicia del barroco decorativo en la zona noroccidental de España." Liño 19: 23-40.

Fernández Fernández, Pelayo. 2014. "Actividades escultóricas en la zona suroccidental de Asturias durante los siglos XVII y XVIII: Ios talleres de Cangas y de Corias." PhD diss., Universidad de Oviedo. Departamento de Historia del Arte y Musicología.

Fernández Suárez, Alberto. 1994. "Patrimonio monumental." In Cangas del Narcea. Ibias. Degaña, 62-114. Oviedo: Real Instituto de Estudios Asturianos.

Fernández Suárez, Alberto, and José Antonio Ron Tejedo. 1997. El patrimonio artístico del concejo de Ibias. Oviedo: Consejería de Cultura del Principado de Asturias.

García Campello, María Teresa. 2005. "Lugo y su entorno: los artistas del siglo XVIII y su obra a través de los protocolos notariales." Boletín del Museo Provincial de Lugo XII: 9-86.

Gómez-Moreno, Manuel. 1942. "Sobre Cornelis de Holanda." El Museo de Pontevedra I: 76-77.

Gómez-Moreno, Manuel. 1963. “Escultura del siglo XVII." In Ars Hispaniae xvi, 124-126. Madrid: Plus-Ultra.

González Álvarez, José María. 2004. "San Cristóbal de Entreviñas." La Maniega 138: 23-29.

González Lafita, Pilar, and Rosa María García Quirós. 1981. "Zona occidental." Liño 2: 131-174.
González Santos, Javier. 1992. "La iglesia de Santa María Magdalena de Cangas del Narcea: puntualizaciones histórico-artísticas a un edificio singular del barroco asturiano." La Maniega 70: 1-12.

González Santos, Javier. 1997. Los comienzos de la escultura naturalista en Asturias (15751625). El legado artístico del arzobispo Valdés Salas y el escultor toresano Juan Ducete Díez. Oviedo: Consejería de Cultura del Principado de Asturias.

González Santos, Javier. 2010. "Templo parroquial de San Salvador de Grandas. Capilla de la Inmaculada en Folgosa. Templo parroquial de Santiago de Pezós." In Grandas de Salime. PesOz, 128-134. Oviedo: RIDEA.

González Santos, Javier. 2014. "Aristócratas en vanguardia: las fundaciones y empresas artísticas de los Queipo de Llano en Asturias en el siglo XVII." In Las ciudades españolas en la Edad Moderna: oligarquías urbanas y gobierno municipal, 386-388. Oviedo: Ediciones KRK.

Gran Enciclopedia Asturiana. 1970. Ed. Silverio Cañada et al. Vol. 8. Gijón: 41.

Gutiérrez Pastor, Ismael. 1994. "Sobre Francisco de Moure y el retablo de Santa María de Beade (Orense): una estatua de Caballero de Malta semiarrodillado." Archivo Español de Arte LXVII: 123-133.

Llamazares Rodríguez, Fernando. 1988. “Entorno al escultor Mateo de Prado." Tierras de León 73: 92-116.

Llamazares Rodríguez, Fernando. 1991. El retablo barroco en la provincia de León. León: Universidad de León.

Llamazares Rodríguez, Fernando. 2008. Fuentes documentales para el arte barroco en la provincia de León. Ensambladores, escultores y pintores. León: Universidad de León.

Llano Roza de Ampudia, Aureliano de. 1928. BeIlezas de Asturias de oriente a occidente. Oviedo: Excma. Diputación Provincial de Oviedo.

López Calderón, María. 2008. “La obra del escultor y arquitecto Francisco de Moure en San Xulián de Samos." In San Xulián de Samos 
historia y arte de un monasterio. Opus monasticorum III, 193-203. Galicia: Xunta de Galicia.

Madoz, Pascual. 1985. Diccionario geográficoestadístico-histórico. Asturias. Ed. Domingo Sánchez Zurro et al. Vol. XI. Valladolid: Ámbito Ediciones.

Manzanares Rodríguez, Joaquín. 1952. "Contribución a la epigrafía asturiana I." Archivum 1-2: 1-29.

Marcos Vallaure, Emilio. 1970. "Juan Alonso Villabrille y Ron, escultor asturiano." Boletín del Seminario de Estudios de Arte y Arqueología XXXVI: 147-158.

Martín González, Juan José. 1998. Escultura barroca en España 1600-1770. Madrid: Ediciones Cátedra.

Mayán Fernández, Francisco. 1949. “El Santuario de Nuestra Señora de Carrasconte. Notas históricas (1578-1828)." Archivos Leoneses (revista del centro de estudios de investigación de San Isidoro) V: 38-94.

Méndez-Valledor y Guzmán, José María. 1985. "Grandas de Salime." In Asturias III, 89-95. Ed. José Luis Pérez de Castro et al. Vol. III. Gijón: Silverio Cañada.

Miguel Vigil, Ciriaco. 1987. Asturias monumental, epigráfica y diplomática. Datos para la historia de la provincia I. Ed. Juan Ignacio Ruiz de la Peña et al. 2 vols. Oviedo: Consejería de Educación, Cultura y Deportes del Principado de Asturias.

Pérez Costanti, Pablo Pérez. 1988. Diccionario de artistas que florecieron en Galicia durante los siglos XVI y XVII. Ed. Ramón Otero Túñez. Xunta de Galicia: Consejería de la Presidencia y Administración Pública.

Peinado Gómez, Narciso. 1951. Lugo monumental y artístico. Lugo: Ediciones Celta.
Ramallo Asensio, Germán. 1985. Escultura barroca en Asturias. Oviedo: IDEA.

Ramallo Asensio, Germán. 1981. "El barroco." In Enciclopedia temática de Asturias, 18-36. Gijón: Silverio Cañada.

Rokiski Lázaro, María Luz. 1991. “Datos documentales sobre la pintura conquense del siglo XVI." Archivo Español de Arte LXIV: 77-85.

San Cristóbal Sebastián, Santos. 1984. La catedral de Mondoñedo. Lugo: Diputación Provincial de Lugo.

Taín Guzmán, Miguel. 1999. "Clasicismo y barroco en tierras mindonienses." Revista de estudios mindonienses. Anuario de estudios histórico-teológicos de la Diócesis de Mondoñedo-Ferrol 15: 469-518.

Trelles Villademoros, José Manuel. 1760. Primitivo origen de la nobleza de España, su antigüedad, clases y diferencias, con la descendencia sucesiva de las principales familias del Reyno. 2. ${ }^{\mathrm{E}} \mathrm{Ed}$. José Manuel Trelles Villademoros. 8 vols. Madrid: Oficina de Domingo Fernández de Arrojo.

Vila Jato, María Dolores. 1980. "Nuevas esculturas de Francisco de Moure." , Boletín Auriense 10: 217-226.

Vila Jato, María Dolores. 1983. Escultura manierista. Orense: Caja de Ahorros Provincial.

Vila Jato, María Dolores. 1987. “Notas sobre el primitivo retablo de San Froilán de la catedral de Lugo." Boletín del Museo Provincial de Lugo III: 49-52.

Vila Jato, María Dolores. 1991. Francisco de Moure. Santiago: Xunta de Galicia.

Vila Jato, María Dolores. 1991. "La primera generación de escultura barroca: Gregorio Fernández y Francisco de Moure." In La escultura gallega: el centenario de Francisco Asorey, 55-65. Santiago de Compostela: fundación Alfredo Brañas. 